Prepared for the U.S. Department of Energy

under Contract DE-AC05-76RL01830

\title{
International Legal Framework for Denuclearization and Nuclear Disarmament - Present Situation and Prospects
}

\author{
ZN Gastelum
}

December 2012

\section{Pacific Northwest} NATIONAL LABORATORY 



\title{
DISCLAIMER
}

This report was prepared as an account of work sponsored by an agency of the United States Government. Neither the United States Government nor any agency thereof, nor Battelle Memorial Institute, nor any of their employees, makes any warranty, express or implied, or assumes any legal liability or responsibility for the accuracy, completeness, or usefulness of any information, apparatus, product, or process disclosed, or represents that its use would not infringe privately owned rights. Reference herein to any specific commercial product, process, or service by trade name, trademark, manufacturer, or otherwise does not necessarily constitute or imply its endorsement, recommendation, or favoring by the United States Government or any agency thereof, or Battelle Memorial Institute. The views and opinions of authors expressed herein do not necessarily state or reflect those of the United States Government or any agency thereof.

\author{
PACIFIC NORTHWEST NATIONAL LABORATORY \\ operated by \\ BATTELLE \\ for the \\ UNITED STATES DEPARTMENT OF ENERGY \\ under Contract DE-AC05-76RL01830
}

Printed in the United States of America
Available to DOE and DOE contractors from the Office of Scientific and Technical Information,
P.O. Box 62, Oak Ridge, TN 37831-0062;
ph: (865) 576-8401
fax: $(865)$ 576-5728
email: reports@adonis.osti.gov

\begin{abstract}
Available to the public from the National Technical Information Service, U.S. Department of Commerce, 5285 Port Royal Rd., Springfield, VA 22161 ph: (800) 553-6847 fax: $(703) 605-6900$ email: orders@ntis.fedworld.gov online ordering: http://www.ntis.gov/ordering.htm
\end{abstract}

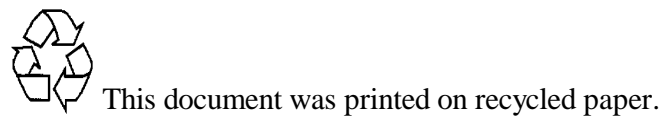




\section{International Legal Framework for Denuclearization and Nuclear Disarmament - Present Situation and Prospects}

ZN Gastelum

December 2012

Prepared for the U.S. Department of Energy under Contract DE-AC05-76RL01830

Pacific Northwest National Laboratory

Richland, Washington 99352 


\section{Contents}

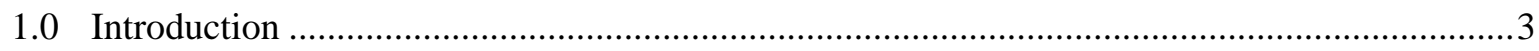

2.0 International Legal Framework for Nuclear Disarmament...................................................6

2.1 Strategic Arms Limitation Talks - SALT I ...............................................................

2.1.1 The Anti-Ballistic Missile (ABM) Treaty (1972) ….........................................

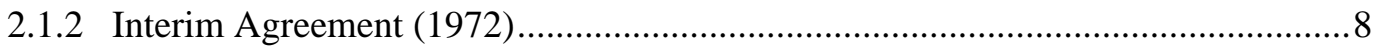

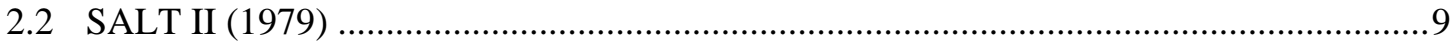

2.3 Intermediate-Range Nuclear Forces Treaty (1987) ..................................................... 11

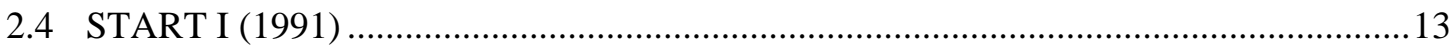

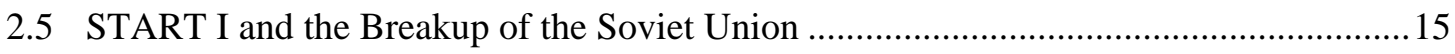

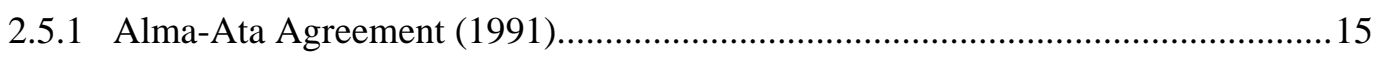

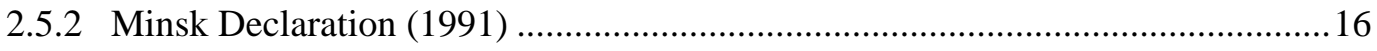

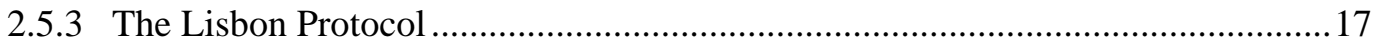

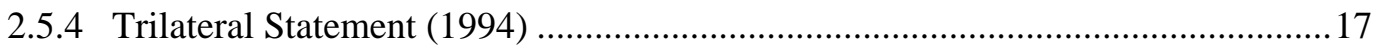

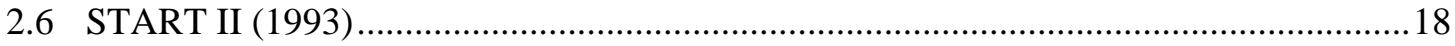

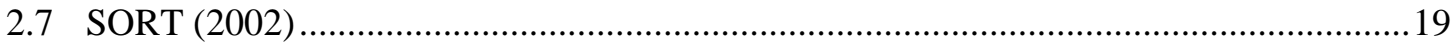

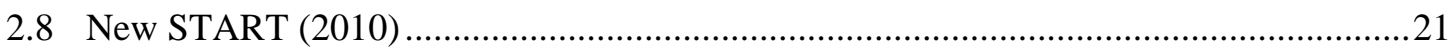

3.0 International Legal Framework for Denuclearization ......................................................23

3.1 Highly Enriched Uranium Purchase Agreement (1993) ...............................................23

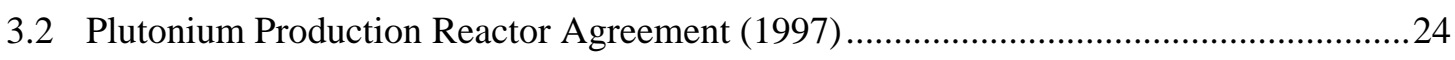

3.3 Plutonium Management and Disposition Agreement (2000) ........................................26

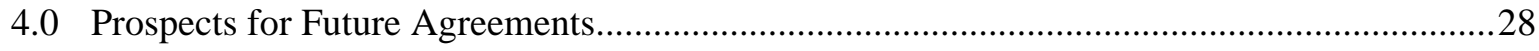

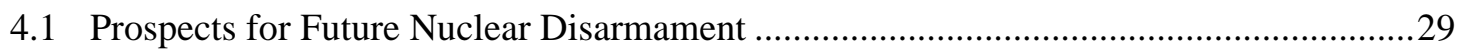

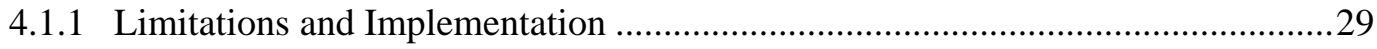

4.1.2 Verification and Monitoring .......................................................................... 32

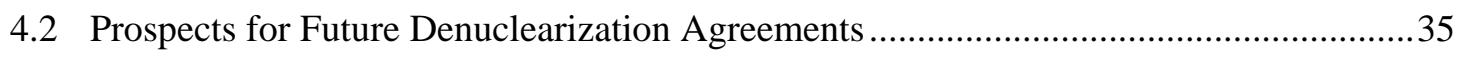

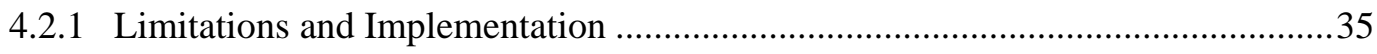

4.2.2 Verification and Monitoring ..........................................................................

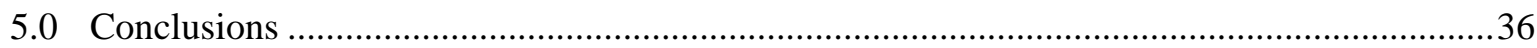




\subsection{Introduction}

Following the use of nuclear devices in World War II, the Cold War resulted in unimaginable proliferation of nuclear weapons technology, mostly among a few, highly technically developed countries. For example, consider the U.S. nuclear stockpile shown in Figure 1, which reached over 31,000 warheads just twenty-one years after the first device was designed.

\section{U.S. Nuclear Weapons Stockpile, 1945-2009*}

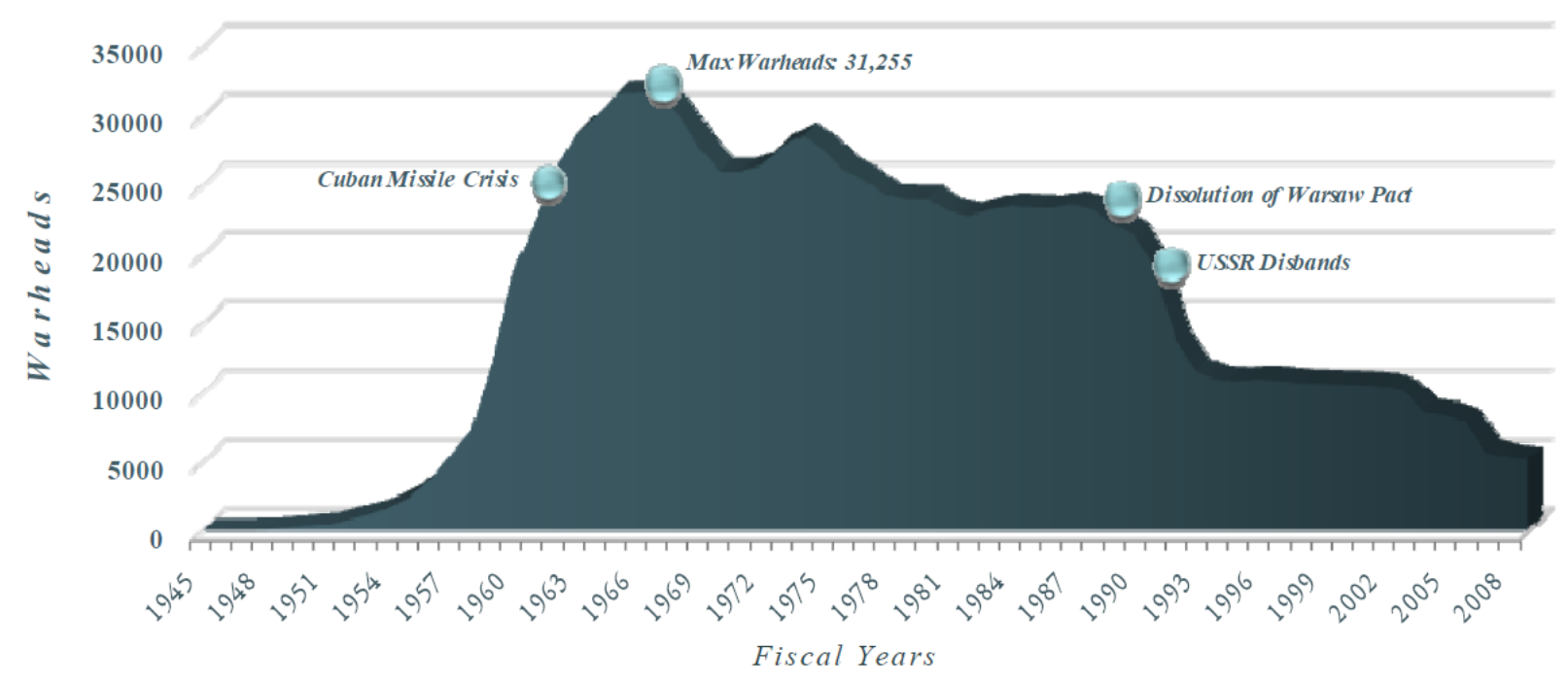

*Includes active and inactive warheads. Several thousand additional nuclear warheads are retired and awaiting dismantlement.

Figure 1 U.S. Nuclear Weapons Stockpile, 1945-2009. ${ }^{1}$

The five Nuclear Weapon States as defined by the Treaty on the Nonproliferation of Nuclear Weapons (NPT, 1968) - the United States, Russia, the United Kingdom, France, and China - are compelled under Article VI to "undertake to pursue negotiations in good faith on effective measures relating to cessation of the nuclear arms race at an early date and to nuclear disarmament, and on a treaty on general and complete disarmament under strict and effective international control." The two nuclear super-powers of the Cold War, the United States and the Soviet Union, did pursue, and agree upon, various treaties to freeze the arms race and begin bilateral nuclear disarmament.

As is the case with international law, precise definitions of terminology are very important in order to articulate what is relevant for specific treaties or conventions. As such, some working definitions will be established for use in this paper.

\footnotetext{
${ }^{1}$ U.S. Department of Defense (2010), "Fact Sheet: Increasing Transparency in the U.S. Nuclear Weapons Stockpile," 03 May 2010, www.defense.gov/npr/docs/10-0503_fact_sheet_us_nuclear_transparency_final_w_date.pdf
} 
According to the Nuclear Threat Initiative, the international community has not yet agreed upon a legal definition of nuclear disarmament. However, international agreements generally describe nuclear disarmament as "the process of reducing the quantity and/or capabilities of military weapons and/or military forces." ${ }^{2}$ For the purpose of this paper, nuclear disarmament will be defined as the act of reducing, limiting, or abolishing nuclear weapons.

The term denuclearization is even less agreed upon in the international community, and appears rarely in the context of arms control and nuclear nonproliferation. For the purpose of this paper, denuclearization will be defined as the elimination of the military infrastructure and materials necessary for nuclear weapons production.

The international community has struggled to define the distinction between strategic and tactical nuclear weapons. Mark Stout of the United States Air Force gives a simple definition. ${ }^{3}$ According to Stout, strategic nuclear weapons are those nuclear weapons which are "delivered strategically", that is, via intercontinental ballistic missiles (ICBMs), submarine-launched ballistic missiles (SLBMs), or heavy bombers. Tactical nuclear weapons are defined as those that are delivered using "battlefield-type delivery systems over battlefield-type distances. However, since the size of a battlefield can vary greatly all we can really say is that they are not strategically-delivered." ${ }^{4}$ For the most part, nuclear disarmament treaties and agreements have specific clauses within the treaty text defining what is covered. For the purposes of general discussion in this paper, the terms strategic and non-strategic will be used, unless referring to language in a specific treaty or agreement.

This paper will begin by providing a historical background to current disarmament and denuclearization treaties. This paper will discuss the current legal framework based on current and historical activities related to denuclearization and nuclear disarmament. Then, it will propose paths forward for the future efforts, and describe the necessary legal considerations. Each treaty or agreement will be examined in respect to its requirements for: 1) limitations and implementation; 2) and verification and monitoring. Then, lessons learned in each of the two areas (limitations and verification) will be used to construct a proposed path forward at the end of this paper.

\section{Limitations and Implementation}

Each treaty or agreement described in this paper will be analyzed first in context of its limitation and implementation requirements. For nuclear disarmament, limitation refers to restrictions, reductions, or eliminations of the development, testing, and deployment of nuclear weapons and their delivery systems. Nuclear disarmament treaties have historically limited or prohibited new developments or deployments, reduced numbers of deployed or non-deployed nuclear arsenals or their delivery systems to a specific goal defined in the treaty text, or eliminated completely a

\footnotetext{
${ }^{2}$ Nuclear Threat Initiative Glossary, www.nti.org/glossary/\#disarmament, accessed 24 October 2012.

${ }^{3}$ Stout, Mark. (2010),“The Tactical versus Strategic Distinction: It's a Big Deal, Right?” The Wright Stuff, 13 May 2010. www.au.af.mil/au/awc/awcgate/nssc/op-ed/tactical_versus_strategic_distinction.pdf, accessed 22 October 2012

${ }^{4}$ Id.
} 
class of weapons. One example is the START I (1991), in which each party was to limit their nuclear weapons over three proscribed phases, until each had no more than:

- 1600 - deployed ICBMs and launchers, deployed SLBMs and launchers, deployed heavy bombers, including 154 deployed heavy ICBMs and their launchers

- 6000 warheads attributed to deployed ICBMs, SLBMs, and heavy bombers, including 4900 warheads attributed to deployed ICBMs and SLBMs, 1100 warheads attributed to deployed ICBMs on mobile ICBM launchers, and 1540 warheads attributed to deployed heavy ICBMs. ${ }^{5}$

Or, in the case of the Intermediate Range Nuclear Forces Treaty (1987), each party agreed to eliminated all intermediate- and shorter- range nuclear capable missiles (between 500 and 5,500 kilometer range), in their arsenals.

Implementation of nuclear disarmament treaties refers to time limits, structures, and other requirements to limit, reduce, and eliminate nuclear weapons and their delivery systems. This could include phased disarmament as discussed above for START I (1991), definitions of how nuclear forces are structured (such as the break-down between ICBMs and SLBMs), and the placement or deployment of those forces (such as how many deployed bases there can be, and where they are allowed to be). If items such as delivery systems are to be destroyed, implementation requirements describe the procedures for properly eliminating them.

For denuclearization, the term limitation refers to restrictions on the production of nuclear weapons-useable materials or components, or the facilities that manufacture them. Historical treaties have included the conversion of facilities so that they no longer produce weaponsuseable materials, the conversion of materials so that they are no longer suitable for weapons purposes, the destruction of such facilities or materials, or agreements to cease additional production of those material or facilities until other denuclearization goals are completed (for example, not producing additional plutonium until excesses are disposed of). For example, under the Plutonium Management and Disposition Agreement (2000), each party agreed to suspend further plutonium separation until the agreed-upon amount of 34 metric tons of plutonium has been dispositioned by each party.

For denuclearization, implementation refers to how the denuclearization process is to occur such as how weapons-useable material is to be disposed of and the requirements for the end product. Similar implementation requirements can be applied to facilities such as the conversion of plutonium production reactors.

\section{Verification and Monitoring}

Verification and monitoring refers to how each party can be assured that the other is in compliance with the agreed-upon terms. Verification and monitoring for both nuclear disarmament and denuclearization has historically consisted of the use of national technical means (NTM), on-site inspections (OSI), exhibitions, or some combination of those. In nuclear disarmament, verification and monitoring can be the examination of a destroyed delivery system, overhead imagery analysis of bases where treaty items are deployed, or counting of shrouded nuclear warheads or using radiation detection equipment to verify that no nuclear materials are

\footnotetext{
${ }^{5}$ START I (1991), Art. II, para. 1.
} 
present. For nuclear disarmament treaties, verification could consist of activities to ensure that no nuclear material is present in a certain delivery vehicle, for example. For denuclearization treaties, one example of verification activities is visits to plutonium production facilities to prove that they are no longer operating or operable. In some cases, it can include the receipt of disposed of or converted material that had been nuclear weapons-useable but has been processed into commercially useable product through commercial contracts.

\subsection{International Legal Framework for Nuclear Disarmament}

This section will discuss the historical background for international legal frameworks for states that have agreed to international nuclear disarmament treaties or agreements and have reduced their arsenals of nuclear weapons and their delivery systems. It will focus on the bilateral treaties agreed upon by the Soviet Union (and later Russia) and the United States. This section will also include a discussion of the transfer of nuclear weapons from the former Soviet states of Ukraine, Kazakhstan, and Belarus to Russia after the collapse of the Soviet Union, in context of the START I agreement.

The majority of all nuclear disarmament agreements have been bilateral agreements between the United States and the Soviet Union (and later Russia). ${ }^{6}$ This section will examine the nuclear disarmament treaties chronologically. Many of the treaties described in this section are no longer in force, either because they have expired, or one or both parties have withdrawn. Two of the agreements discussed in this section are currently in-force: The Intermediate-Range Nuclear Forces Treaty (1987), which eliminated an entire class of missiles in the United States and Russia and remains in-force indefinitely, and the New START (2010) between the United States and Russia to bring down levels of strategic forces in the two parties, which is to remain in-force for ten years, with a possible five-year extension. These two treaties, in addition to the historical treaties, provide the framework for future nuclear disarmament agreements.

Figure 2 below offers a high-level summary of the status and scope of current and historical nuclear disarmament treaties. Most of the treaties listed in the table will be covered in additional detail later in this section.

\footnotetext{
${ }^{6}$ The case of South Africa is unique and compelling when examining nuclear disarmament in general. The country was the first and only state to voluntarily dismantle nuclear weapons after developing them. The South African nuclear weapons program is reported to have developed six nuclear weapons by 1991. Amid an improving national security environment, and seeking to reintegrate into the international community, South African President de Klerk issued instructions on February 26, 1990 on implementing the termination of the country's nuclear weapons program. In 1991, South Africa joined the Nuclear Nonproliferation Treaty as a Non-Nuclear Weapons State, and shortly thereafter signed a safeguards agreement with the IAEA. Twenty one months after the beginning of implementing safeguards in South Africa, in September 1993, the IAEA accepted the completeness of South Africa's inventory of nuclear materials and facilities, and the declarations on dismantlement and destruction of hardware from nuclear devices, reassignment of dual-use technologies to non-nuclear or peaceful use, and destruction of two test shafts under IAEA supervision. Throughout the 21 month process of verifying the declarations, RSA provided access "anywhere, any time, and place - within reason". This will be a difficult mold to follow in the future. Because South Africa chose to unilaterally disarm outside of the realm of international law, it will not be covered further in this paper.
} 


\begin{tabular}{|c|c|c|c|c|c|c|c|}
\hline \multicolumn{8}{|c|}{ Strategic Nuclear Arms Control Agreements } \\
\hline & SALT I & SALT II & START I & START II & START III & SORT & New START \\
\hline Status & Expired & \begin{tabular}{|l|} 
Never \\
Entered Into \\
Force \\
\end{tabular} & Expired & \begin{tabular}{|l} 
Never \\
Entered Into \\
Force
\end{tabular} & $\begin{array}{l}\text { Never } \\
\text { Negotiated }\end{array}$ & $\begin{array}{l}\text { Replaced by } \\
\text { New START }\end{array}$ & In Force \\
\hline $\begin{array}{l}\text { Deployed } \\
\text { Warhead Limit }\end{array}$ & NA & NA & 6,000 & $3,000-3,500$ & $2,000-2,500$ & $1,700-2,200$ & 1,550 \\
\hline $\begin{array}{l}\text { Deployed } \\
\text { Delivery } \\
\text { Vehicle Limit }\end{array}$ & $\begin{array}{l}\text { US: } 1,710 \\
\text { ICBMS \& } \\
\text { SLBMs } \\
\text { USSR: } 2,347\end{array}$ & 2,250 & 1,600 & NA & NA & NA & $\begin{array}{l}700 ; 800 \\
\text { including non- } \\
\text { deployed }\end{array}$ \\
\hline Date Signed & May 26,1972 & \begin{tabular}{|l} 
June 18, \\
1979
\end{tabular} & \begin{tabular}{|l}
$\begin{array}{l}\text { July } 31, \\
1991\end{array}$ \\
\end{tabular} & Jan. 3, 1993 & NA & May 24, 2002 & April 8, 2010 \\
\hline $\begin{array}{l}\text { Date Ratifed, } \\
\text { U.S. }\end{array}$ & Aug. 3, 1972 & NA & Oct. 1, 1992 & $\begin{array}{l}\text { Jan. 26, } \\
1996\end{array}$ & NA & $\begin{array}{l}\text { March 6, } \\
2003\end{array}$ & Dec. 22,2010 \\
\hline $\begin{array}{l}\text { Ratification } \\
\text { Vote, U.S. }\end{array}$ & $88-2$ & NA & $93-6$ & $87-4$ & NA & $95-0$ & $71-26$ \\
\hline $\begin{array}{l}\text { Date Entered } \\
\text { Into Force }\end{array}$ & Oct. 3, 1972 & NA & Dec. 5, 1994 & NA & NA & June 1, 2003 & Feb. 5, 2011 \\
\hline $\begin{array}{l}\text { Implementation } \\
\text { Deadline }\end{array}$ & NA & NA & Dec. 5, 2001 & NA & NA & NA & Feb. 5, 2018 \\
\hline Expiration Date & Oct. 3,1977 & NA & Dec. 5, 2009 & NA & NA & Feb. 5, 2011 & Feb. 5, 2021 \\
\hline
\end{tabular}

Figure 2 Stratgic Nuclear Arms Control Agreements ${ }^{7}$

\subsection{Strategic Arms Limitation Talks - SALT I}

Early efforts to begin strategic arms limitation talks (SALT) were not widely successful. United States President Lyndon Johnson announced on July 1, 1968, upon U.S. signature of the Nuclear Nonproliferation Treaty (NPT, 1968), that the United States and Soviet Union had agreed to start talks. Two months later, when the USSR invaded Czechoslovakia, talks were postponed indefinitely. Eventually, negotiations were held between November 1969 to May 1972, during which time the United States and the Soviet Union negotiated their first agreement to limit and restrain arms. The negotiations resulted in the signature of two agreements: the Anti-Ballistic Missile Treaty (1972), and the Interim Agreement (1972). ${ }^{8}$

\subsubsection{The Anti-Ballistic Missile (ABM) Treaty (1972)}

Long Name: The Treaty between the United States of America and the Union of Soviet Socialist Republics on the Limitation of Anti-Ballistic Missile Systems

Signed: May 26, 1972

Entered into force: October 3, 1972

Current Status: Not in force

The ABM Treaty comprehensively limited the development and deployment of ABM systems and allowed for withdrawal after six-months' notice only in the case that a state finds that its

\footnotetext{
${ }^{7}$ Sohn, Mike and Hal Undem (2012), Nuclear Weapons Treaties. Presented to the PNNL Arms Control Seminar Series, Pacific Northwest National Laboratory, Richland, WA, USA, 19 October 2012.

${ }^{8}$ U.S. Department of State, Strategic Arms Limitation Talks (SALT I) (narrative), www.state.gov/t/isn/5191.htm, accessed 24 October 2012.
} 
"supreme interests are jeopardized by "extraordinary events." " On December 13, 2001, in the aftermath of the September $11^{\text {th }}$ terrorist attacks, the United States announced its intent to withdraw from the Treaty. U.S. President George Bush announced that "the ABM treaty hinders our government's ability to develop ways to protect our people from future terrorist or rogue state missile attacks." ${ }^{10}$ Per Article XV of the Treaty, American withdrawal became effective six months after its notification to Russia.

\section{Limitations and Implementation}

The ABM Treaty restrained each Party to two ABM deployment sites: one site to protect the nation's capital, and one site to protect ICBM launch sites. ${ }^{11}$ Later, the 1974 Protocol modified Article II of the Treaty and reduced ABM deployments to only one site in each country. ${ }^{12}$ Article II of the ABM Treaty limited each Party to have no more than 100 interceptor missiles, and 100 launchers, with additional limitations on ABM radars. Any capability in excess to that specified in Article II was to be dismantled and destroyed, according to Article VIII.

The ABM Treaty specified that the two ABM sites must be at least 1300 kilometers apart, in order to prevent either country from having or developing a national ABM defense. Each ABM area was to have a diameter of no more than $300 \mathrm{~km}$, with no more than two large phased-array ABM radars and no more than eighteen ABM smaller radars (Art III). The ABM Treaty put limits on qualitative development of ABM systems, including the development, testing, or deployment of ABM launchers capable of launching multiple ABMs at one time, or capable of rapid reloads, or upgrade current systems to have that capability under Article V. In addition to the domestic deployment limitations, Article IX prohibited the Parties from deploying ABM systems or components outside of their national territory.

\section{Verification and Monitoring}

Verification procedures for the ABM Treaty are defined in Article XII, as the use of national technical means (NTM). ${ }^{13}$ In addition, each Party agreed to comply with verification by not interfering with the NTM of another country or through deliberate concealment. ${ }^{14}$

\subsubsection{Interim Agreement (1972)}

Long Name: The Interim Agreement between The United States of America and The Union of Soviet Socialist Republics on Certain Measures With Respect to the Limitation of Strategic Offensive Arms (1972)

Signed: May 26, 1972

Entered into force: October 3, 1972

Current Status: Expired October 3, 1977

\footnotetext{
${ }^{9} \mathrm{Id}$.

${ }^{10}$ CNN (2001), U.S. Quits ABM Treaty. 03 December 2001. http://articles.cnn.com/2001-1213/politics/rec.bush.abm_1_abm-treaty-rogue-state-missile-attacks-anti-ballistic-missiletreaty?_s=PM:ALLPOLITICS, accessed 24 October 2012.

11 ABM Treaty (1972), Article III.

12 Protocol to the Treaty Between the United States of America and the Union of Soviet Socialist Republics On the Limitation Of Anti-Ballistic Missile Systems (1974), Article I, para. 1.

${ }^{13}$ ABM (1972), Article XII, para. 1.

${ }^{14}$ ABM (1972), Article XII, paras. 2 and 3.
} 
Though the Interim Agreement did not attempt to disarm either state, it did serve as a stop-gap that could ease tensions to allow both states to negotiate for a decrease in strategic armaments. It froze the parties at their current levels of ICBMs and SLBMs, and was interpreted as a holding action, to limit competition between the United States and Soviet Union, and give time for additional negotiations. ${ }^{15}$ As noted in the preamble of the agreement, the agreement sought to provide "more favorable conditions for active negotiations on limiting strategic arms as well as to the relaxation of international tensions." 16 The agreement was significant as being the first by which the United States and Soviet Union could agree on some level of nuclear disarmament discussions, which had been under negotiation for several years.

\section{Limitations and Implementation}

In Article I of the Interim Agreement, the parties agreed not to start construction of additional land-based ICBMs after July 1, 1972. In addition, under Article II, the parties agreed not to convert land-based launchers to ICBMs or convert older ICBMs to heavy ICBMs. The Parties agreed to limit SLBMs to the number of operational and under construction at the date of signature, May 26, 1972. ${ }^{17}$

\section{Implementation}

The Interim Agreement does not specify reductions in force, the structure of those forces, or other requirements. It was a freeze only on additional development (both quantitative and qualitative), so reductions and force structure are presumed to stay the same. Modernization and replacement of strategic offensive ballistic missiles and launchers was provided for in the Agreement under Article IV, as long as those modernization activities did not violate other terms (such as those in Article II or III).

\section{Verification and Monitoring}

The Interim Agreement provided for verification through national technical means (NTM), in Article V. As with the ABM Treaty, both Parties agreed not to interfere with the other's NTM, and not to undertake concealment activities that would inhibit the other's NTM.

\subsection{SALT II (1979)}

Long Name: The Treaty Between the United States of America and the Union of the Soviet Socialist Republics on the Limitation of Strategic Offensive Arms

Signed: June 18, 1979

Entered into force: Never

Current Status: Never entered into force

\footnotetext{
${ }^{15}$ U.S. Department of State. Interim Agreement Between the United States of America and the Union of the Soviet Socialist Republics on Certain Measures with Respect to the Limitation of Strategic Offensive Arms (narrative). www.state.gov/t/isn/4795.htm\#treaty, accessed 07 November 2012.

${ }^{16}$ Interim Agreement (1972), Preamble.

${ }^{17}$ Interim Agreement (1972), Article III.
} 
The United States and Soviet Union began negotiations for SALT II in November 1972, to replace the Interim Agreement (1972) and begin mutual reductions in force. The treaty was expected to initially reduce the number of strategic nuclear delivery systems to the same level for each party, and then continue joint reductions and restrain modernization or improvements that could threaten stability. ${ }^{18}$ Negotiations for SALT II were completed on June 18, 1979. In 1980, President Carter requested that the Senate delay ratification because of the Soviet invasion of Afghanistan. ${ }^{19}$ Each party committed to comply with their side of the agreement even before proper ratification or entry into force, but due to political disagreements the Treaty was never ratified, and never entered into force..$^{20}$

\section{Limitations and Implementation}

Under SALT II, the parties agreed to limit their strategic arsenals' delivery systems. In Article III paragraphs 1 and 2, the parties agreed to limit ICBM launchers, SLBM launchers, heavy bombers, and air-to-surface ballistic missiles (ASBMs) to 2,400 upon entry into force, and not to exceed an aggregate number of 2250 by January 1, 1981. In the Treaty's Joint Statement of Principles, ${ }^{21}$ the Parties agreed to pursue negotiations for "measures for the further limitation and reduction in the numbers of strategic arms, as well as for their further qualitative limitation," to strengthen verification, and consider steps to enhance strategic stability.

The parties retained their right to determine the structure of their strategic forces as long as the aggregate number of delivery systems stayed within the limits agreed upon in Article III paragraphs 1 and 2 (explained above). ${ }^{22}$ In addition, in Article IV, the parties agree to not start construction of additional fixed ICBM launchers, not to relocate fixed ICBM launchers, and not to modernize, update or convert ICBMs and silo launchers. Both parties also agreed to not test, develop or deploy new capabilities related to ICBM launchers or rapid reload systems. The Protocol to the Treaty ${ }^{23}$ covers issues such as deployment and testing of ICBMs, cruise missiles, and ASBMs.

\section{Verification and Monitoring}

Similarly to the verification measures agreed upon in SALT I, SALT II was to be verified through the use of NTM, without interference or concealment from each party. ${ }^{24}$ In addition to NTM, SALT II added an additional verification measure - telemetry. Telemetry is the electronic signals that are used to broadcast information about a missile test. Under SALT II, telemetric

\footnotetext{
${ }^{18}$ U.S. Department of State, Treaty Between The United States of America and The Union of Soviet Socialist Republics on the Limitation of Strategic Offensive Arms (SALT II), www.state.gov/t/isn/5195.htm, accessed 14 October 2012.

${ }^{19}$ Id.

${ }^{20} \mathrm{Id}$.

${ }^{21}$ Joint Statement of Principles and Basic Guidelines for Subsequent Negotiations on the Limitation of Strategic Arms (1979).

${ }^{22}$ SALT II (1979), Article III, para. 3.

${ }^{23}$ Protocol to the Treaty Between The United States of America and The Union of Soviet Socialist Republics on the Limitation of Strategic Offensive Arms, Together With Agreed Statements and Common Understandings Regarding the Protocol (1979).

${ }^{24}$ SALT II (1979), Article XV.
} 
information could be used for verification, and the treaty required that "neither Party shall engage in deliberate denial of telemetric information." 25

\subsection{Intermediate-Range Nuclear Forces Treaty (1987)}

Long Name: The Treaty between the United States of America and the Union of Soviet Socialist Republics on the Elimination of Their Intermediate-Range and Shorter-Range Missiles

Signed: December 8, 1987

Entered into Force: June 1, 1988

Current Status: In force

The Intermediate-Range Nuclear Forces (INF) Treaty was a landmark agreement between Russia and the United States, in part because of its use of intrusive verification provisions, but also as a model on how to eliminate an entire class of missiles. The INF Treaty entered into force June 1, 1988, and remains in-force indefinitely. ${ }^{26}$ In May 1991, the United States and the Soviet Union both eliminated their last missile systems covered under the INF Treaty. A total of 2,692 missiles were eliminated after the Treaty's entry-into-force. ${ }^{27}$ The breakup of the Soviet Union in December 1991 resulted in six countries with facilities that were considered to be INFinspectable. Today, four of the six INF successor states (Belarus, Kazakhstan, Russia, and Ukraine) are active participants in the treaty, and Turkmenistan and Uzbekistan (each with only one treaty-relevant site on its territory) have assumed less active roles. ${ }^{28}$ INF inspections ceased as of June 1, 2001 after all INF missile systems were eliminated. ${ }^{29}$

\section{Limitations and Implementation}

The INF Treaty requires complete elimination of intermediate-range nuclear capable missiles. Under Article I, each party shall eliminate its intermediate- and shorter-range missiles, and will not have them in the future. Article II defines "intermediate-range" as ground-launched ballistic missiles (GLBM) or ground-launched cruise missiles (GLCM) with a range between 1000 to 5500 kilometers, ${ }^{30}$ and shorter-range missiles between $500-1000$ kilometers. ${ }^{31}$

The treaty requires destruction of the parties' ground-launched ballistic and cruise missiles with ranges of between 500 and 5,500 kilometers, their launchers and associated support structures and support equipment within three years of the treaty's entrance into force. Under the INF treaty, both parties agree to completely eliminate their intermediate-range missiles within three years of entry into force of the treaty. Under Article IV of the treaty, each party is to eliminate all of its intermediate range missiles and their launchers and support equipment within three years of entry into force of the treaty, in two phases. In the first phase, defined in Article V, each party

\footnotetext{
${ }^{25}$ SALT II (1979), Art XV, para. 3, Second Common Understanding.

${ }^{26}$ U.S. Department of State. Treaty Between the United States of America And The Union of Soviet Socialist Republics On The Elimination Of Their Intermediate-Range And Shorter-Range Missiles (INF Treaty), www.state.gov/t/avc/trty/102360.htm, accessed 14 October 2012.

${ }^{27}$ Id.

${ }^{28} \mathrm{Id}$.

${ }^{29}$ Defense Threat Reduction Agency (2012), Treaty Information Center

http://dtirp.dtra.mil/tic/implementation_status.aspx, accessed 31 October 2012.

${ }^{30}$ INF Treaty (1987), para. 4.

${ }^{31}$ INF Treaty (1987), para. 5.
} 
completely eliminated completely their shorter-range missiles, launchers, and support equipment within 18 months of entry into force of the treaty. In the second phase, which ends no later than three years after entry into force, the parties must eliminate all intermediate-range missiles, their launchers, and their support structures.

In addition, upon entry into force of the treaty, neither party shall produce any stages or components of, or flight-test, intermediate- or shorter-range missiles or launchers. ${ }^{32}$ The 1987 Elimination Protocol ${ }^{33}$ defines the items for each missile system to be eliminated, and the procedures to eliminate or destroy each item covered under the treaty.

\section{Verification and Monitoring}

The INF treaty provided the most intrusive verification measures seen to that point in time in a nuclear disarmament treaty. On-site inspections to verify the elimination of missile systems is provided for in Article $\mathrm{X}$ of the INF treaty. Additional rules and procedures for on-site inspections, including the obligations of each party during inspections, requirements for inspector designations, notifications of inspections, rules and procedures for inspection activities, and post-inspection reporting, with additional rules and procedures, are in the Inspections Protocol (1987). ${ }^{34}$ Article XI provides allowed timelines for notification and inspection activities of OSIs on missile bases, ${ }^{35}$ and elimination verification. ${ }^{36}$ It also breaks down how many OSIs shall be carried out during the 13 years of inspection activities provided for the treaty, with no more than: ${ }^{37}$

- 20 inspections per year for the first three years

- 15 inspections per year for the following five years

- 10 inspections per year for the last five years

Article IX of the treaty defines the exchanges of data and other information to support verification activities. The Memorandum of Understanding Regarding The Establishment of the Data Base, ${ }^{38}$ signed December 8, 1987, defines what is meant by each item that is to be counted in the data base, and provides a baseline of number of intermediate- and shorter-range missiles, launchers, and support systems subject to the treaty in each country as of November 1, 1987, as well as their locations.

Article XII contains the typical NTM provisions - that NTM shall be used to support verification of compliance with the treaty, without interference or concealment measures from the other state. In addition, it provides for cooperative measures on NTM for missiles with over $5500 \mathrm{~km}$ ranges, whereby states will provide "open roof access" for NTM verification for the other state, up to six

\footnotetext{
${ }^{32}$ INF Treaty (1987), Article VI.

${ }^{33}$ Protocol On Procedures Governing The Elimination Of The Missile Systems Subject To The Treaty Between The United States Of America And The Union Of Soviet Socialist Republics On The Elimination Of Their IntermediateRange And Shorter-Range Missiles (1987).

${ }^{34} \mathrm{Id}$.

${ }^{35}$ INF Treaty (1987), para. 3

${ }^{36}$ Id., para. 4

${ }^{37}$ Id., para. 5

${ }^{38}$ The Memorandum Of Understanding Regarding The Establishment Of The Data Base For The Treaty Between The Union Of Soviet Socialist Republics And The United States Of America On The Elimination Of Their Intermediate- Range And Shorter-Range Missiles (1987).
} 
times per year. "Open roof access" refers to physically removing or opening the roofs from fixed structures for missile launchers and displaying those missiles in the open, so that they may be viewed via NTM. ${ }^{39}$

\subsection{START I (1991)}

Long Name: The Treaty Between the United States of America and the Union of Soviet Socialist Republics on the Reduction and Limitation of Strategic Offensive Arms (START)

Signed: July 31, 1991

Entered into force: December 5, 1994

Current Status: Expired December 5, 2009

Unlike previous SALT agreements - SALT I which froze force levels, and SALT II which never entered into force - START aimed to reduce numbers of strategic weapons held by both parties. This was especially significant in that it is the first treaty to come into force that would actually reduce the parties' nuclear arsenals. INF, however, may have provided positive momentum for the agreement, in that the states were able to agree on eliminating a complete class of missiles, with intrusive verification.

\section{Limitations and Implementation}

START I, under Article II, limits ICBMs and SLBMs launchers and warheads, and heavy bombers and their armaments within seven years after entry into force to the following amounts:

- 1600 - deployed ICBMs and launchers, deployed SLBMs and launchers, deployed heavy bombers, including 154 deployed heavy ICBMs and their launchers

- 6000 warheads attributed to deployed ICBMs, SLBMs, and heavy bombers, including 4900 warheads attributed to deployed ICBMs and SLBMs, 1100 warheads attributed to deployed ICBMs on mobile ICBM launchers, and 1540 warheads attributed to deployed heavy ICBMs.

The treaty uses "attributable warheads" as a unit of measure, meaning the number of warheads that each type of delivery system was capable of carrying. This system of using "attributed warheads" was new to the arms control agreements, whereby previously only the delivery systems themselves were counted.

The arms reductions were to be implemented in three phases, each of which had corresponding arms limitation levels. In the first phase, within 36 months of entry into force of the treaty, aggregate limits were: ${ }^{40}$

- 2100, for deployed ICBMs and their associated launchers, deployed SLBMs and their associated launchers, and deployed heavy bombers;

- 9150, for warheads attributed to deployed ICBMs, deployed SLBMs, and deployed heavy bombers;

- 8050 , for warheads attributed to deployed ICBMs and deployed SLBMs

\footnotetext{
${ }^{39}$ See INF (1987) Art XII, para. 3.

${ }^{40}$ START I (1991), para. 2(a).
} 
The second phase, which was to be completed within 60 months of entry into force of the agreement, set the following aggregate limits: ${ }^{41}$

- 1900 , for deployed ICBMs and their associated launchers, deployed SLBMs and their associated launchers, and deployed heavy bombers;

- 7950, for warheads attributed to deployed ICBMs, deployed SLBMs, and deployed heavy bombers;

- $\quad 6750$, for warheads attributed to deployed ICBMs and deployed SLBMs

Finally, in the third phase, which was to be completed within 60 months of the treaty's entrance into force, each party was to have the aggregate numbers listed Article II paragraph 1:

- 1600 - deployed ICBMs and launchers, deployed SLBMs and launchers, deployed heavy bombers, including 154 deployed heavy ICBMs and their launchers

- 6000 warheads attributed to deployed ICBMs, SLBMs, and heavy bombers, including 4900 warheads attributed to deployed ICBMs and SLBMs, 1100 warheads attributed to deployed ICBMs on mobile ICBM launchers, and 1540 warheads attributed to deployed heavy ICBMs.

Article IV of the treaty specified how many ICBMs and SLBMs could be at different types of sites (i.e. non-deployed, in the upper atmosphere, or at a test range). Article $\mathrm{V}$ of the treaty described limitations on modernization, replacement, production, testing, deployment, and conversion of certain categories of ICBMs and SLBMs.

\section{Verification and Monitoring}

As with previous arms control treaties, the START Treaty allowed for NTM to support verification of compliance with the treaty. Article IX includes prohibitions of interference or concealment from the other party. As with the INF Treaty, Article XII of START I requires open displays of certain treaty items in order to facilitate NTM verification activities, and Article XII requires open displays of certain ICBMs, ICBM launchers, and heavy bombers for NTM. Article IX also requires that ICBMs and mobile ICBM launchers have unique identifiers to assist in verification.

In addition, building on the sharing of telemetric data which was to be established under SALT II, under Article $\mathrm{X}$ the parties agreed to broadcast technical measurements and telemetric data from flight-testing ICBMs and SLBMs.

Finally, Article XI contained provisions for inspections, continuous monitoring, and exhibitions. Article XI established the rights of each party to conduct onsite inspections (OSI) and their obligation to conduct exhibitions, including inspections to establish baseline data, confirm accuracy from exchanged data, and to confirm conversion or elimination of systems. Each party

\footnotetext{
${ }^{41}$ START I (1991), para. 2(b).
} 
was also required to conduct technical exhibitions. The Inspection Protocol ${ }^{42}$ and the Conversion or Elimination Protocol provided additional instructions and regulations for how the limitations, implementation, and verification were to be carried out. ${ }^{43}$

\subsection{START I and the Breakup of the Soviet Union}

The breakup of the Soviet Union in December 1991 caused a significant turn of events into the U.S.-USSR bilateral talks on nuclear disarmament. ${ }^{44}$ It was not immediately clear under international law which states succeeded to the international obligations of the USSR. The breakup resulted in four sovereign states with nuclear weapons (Russia, Belarus, Kazakhstan, and Ukraine), none of which had signed the START I agreement with the United States. Russia worked quickly to secure agreements to have all nuclear weapons and their delivery systems returned as soon as possible to Russian soil.

The three newly nuclear states that resulted from the breakup of the Soviet Union therefore made arrangements with Russia and the United States to remove nuclear weapons from their territories, join the Nuclear Nonproliferation Treaty (1968) as Non-Nuclear Weapons States, and sign safeguards agreements with the International Atomic Energy Agency (IAEA). One such agreement is the Lisbon Protocol, which multilateralized the START I Treaty to include all four of the former Soviet States with nuclear weapons. There were several additional agreements aimed at transferring and consolidating nuclear weapons in Russia, and bringing those weapons, as well as the former Soviet states, into the legal framework of the START and the NPT. Though these agreements differ in nature from the strictly bilateral agreements between the United States and the Soviet Union up to that point, they play an important role in understanding the historical context of the time.

\subsubsection{Alma-Ata Agreement (1991)}

Long Name: The Agreement on Joint Measures with Respect to Nuclear Weapons, also known as the Alma Ata Agreement

Signed: December 21, 1991

Entered into force: Never

Current Status: NA, never entered into force

The Alma Alta Agreement is not under the auspices of the START I, but it is important to examine here as an effort to consolidate the nuclear arsenal of the former Soviet Union in Russia. The Alma-Ata Agreement establishes a commitment by Belarus, Kazakhstan, and Ukraine to cede nuclear weapons on their territories to Russia by July 1992.

\footnotetext{
${ }^{42}$ Protocol on Inspections and Continuous Monitoring Activities Relating to the Treaty Between the United States of America and the Union of Soviet Socialist Republics on the Reduction and Limitation of Strategic Offensive Arms (1991).

${ }^{43}$ Protocol on Procedures Governing the Conversion or Elimination of the Items Subject to the Treaty Between the United States of America and the Union of Soviet Socialist Republics on the Reduction and Limitation of Strategic Offensive Arms (1991).

${ }^{44}$ Reiss, Mitchell (1995), Bridled Ambition, Woodrow Wilson Center Press, Washington, D.C. pp. 97.
} 
The primary goal of the Alma-Alta Agreement was to completely remove and destroy the nuclear weapons in Belarus, Kazakhstan and Ukraine. In addition to providing for the transfer of nuclear weapons in Belarus, Kazakhstan, and Ukraine back to Russia for destruction, the agreement provided for significant policy cooperation between the states until the agreement was fully carried out. Article 3 stated that participating states will "jointly develop" policy on issues. This point is expanded in Article 4, which stated that until nuclear weapons are removed completely from Belarusian and Ukrainian territories, the Russian President shall seek the consent of the participating states before using nuclear weapons.

Under Article 5 of the agreement, Belarus and Ukraine agreed to sign the Nuclear Nonproliferation Treaty (1968) as Non-Nuclear Weapon States (NNWS), and to sign the corresponding safeguards agreements with the IAEA (Russia would be a Nuclear Weapon State, or NWS). Belarus, Ukraine, and Kazakhstan agreed not to transfer nuclear weapons or nuclear explosive devices to other countries, except back to the territory of Russia for their destruction. Article 7 of the agreement committed the governments of Belarus, Kazakhstan, Russia, and Ukraine to submit the "Treaty on the Reduction and Elimination of Strategic Offensive Arms" for ratification.

The agreement called for the withdrawal of all tactical nuclear weapons from Belarus, Kazakhstan and Ukraine, and transfer to "central bases" for "dismantling under joint control" by July 1, 1992 ${ }^{45}$. Ukraine and Kazakhstan also had bilateral agreements with Russia on how the disarmament would take place. There was no formal agreement with Belarus. ${ }^{46}$ The United States also negotiated "side letters" with Ukraine, Kazakhstan and Belarus that all nuclear weapons would be returned to Russia. ${ }^{47}$

\subsubsection{Minsk Declaration (1991)}

Long Name: The Agreement on Strategic Forces

Signed: December 30, 1991

Entered into force: December 30, 1991

Current Status: Expired upon withdrawal of strategic forces and nuclear weapons from Belarus, Kazakhstan and Ukraine.

The Minsk Declaration, also known as the Agreement on Strategic Forces, was concluded by the 11 members of the Commonwealth of Independent States (CIS) as part of the Minsk Summit, just nine days after the Alma-Ata Agreement, on December 30, 1991. The summit was to determine how the former USSR's obligations related to international security would be borne by the CIS, specifically the joint command and destruction of strategic nuclear weapons. The Minsk declaration placed all of the nuclear weapons on Ukrainian soil under joint command. Under Article 4, it reiterated the need for complete elimination of nuclear weapons from Belarus, Kazakhstan, and Ukraine.

\footnotetext{
${ }^{45}$ Alma-Ata Agreement (1991), Article VI.

${ }^{46}$ Reiss, op. cit., pp. 94-133.

${ }^{47}$ Reiss, op. cit., pp. 98-146.
} 
Article II established that the former Soviet states would observe USSR's international treaties related to international security, disarmament and arms control, and enter into negotiations on how to implement them. Under Article VI, the agreement entered into force immediately upon signature. Article 3 of the agreement detailed some of the nuclear weapons policy that began to take shape in the Alma-Ata agreement. It outlined the need for joint command of strategic forces and for maintaining unified control of nuclear weapons among the CIS. Article 4 specified that, until the nuclear weapons located in Ukraine are completely destroyed, they shall be under joint control via the Combined Strategic Forces Command. It noted that all nuclear weapons in Ukrainian territory would be dismantled by the end of 1994, including tactical weapons by July $1,1992$.

\subsubsection{The Lisbon Protocol}

Long Name: Lisbon Protocol

Signed: May 23, 1992

Entered into Force: December 5, 1994

Current Status: Expired

The Lisbon Protocol ${ }^{48}$ established Ukraine, Belarus, Kazakhstan and Russia as successors of the USSR in relation to the former country's obligations under the START (1991) as of April 1992. In addition, under Article V, Belarus, Kazakhstan, and Ukraine agreed to join the NPT as NNWS in "the shortest possible time." Under Article I, Belarus, Kazakhstan, Russia, and Ukraine are defined as the successors to the USSR, and assume obligations of the former USSR under the START. Under Article II, the successor states defined above would make the necessary arrangements to implement START restrictions, allow for verification, and allocate costs. The limitations, implementation, and verification would fall under the auspices of the START I agreement.

\subsubsection{Trilateral Statement (1994)}

Long Name: The Trilateral Statement of the Presidents of the United States of America, Ukraine, and the Russian Federation

Signed: January 14, 1994

Entered into Force: January 14, 1994

Current Status: Expired 2001

The signing of the Trilateral Statement in Moscow in January 1994 was seen as a significant success in ridding Ukraine of nuclear weapons. Under the agreement, the Russian Federation sent 100 tons of fuel to Ukraine for its nuclear power plants. The United States agreed to pay \$60 million to the Russian Federation in support of that process. For its part, Ukraine agreed to transfer 200 nuclear warheads over a 10 -month period. ${ }^{49,50}$

\footnotetext{
${ }^{48}$ Protocol to the Treaty between the United States of America and the Union of the Soviet Socialist Republics on the Reduction and Limitation of Strategic Offensive Arms (1992).

${ }^{49}$ Federation of American Scientists, Ukraine Special Weapons, www.fas.org/nuke/guide/ukraine/, accessed 09 October 2012.

${ }^{50}$ Reiss, op. cit., pp. 117.
} 
The annex of the statement specified that "all nuclear warheads will be transferred from the territory of Ukraine to Russia for the purpose of their subsequent dismantling in the shortest possible time." The annex of the Joint Statement provided the "meat" of the agreement. In the annex, Russia agreed to provide Ukraine within ten months, fuel assemblies for nuclear power stations containing 100 tons of low-enriched uranium. Ukraine agreed to transfer at least 200 nuclear warheads from RS-18(SS-19) and RS-22 (SS-24) missiles to Russia for dismantling by the date that the fresh fuel was received. The United States underwrote the funding for the agreement, and agreed to provide $\$ 60$ million as an advance payment to Russia, to be deducted from payments due to Russia under the highly-enriched uranium contract. These funds would be available to help cover expenses for the transportation and dismantling of strategic warheads and the production of fuel assemblies. The annex set a seven-year time limit for Ukraine to eliminate all of the nuclear weapons in its territory.

\subsection{START II (1993)}

Long Name: Treaty Between the United States of America and the Russian Federation on Further Reduction and Limitation of Strategic Offensive Arms

Signed: January 3, 1993

Entered into force: Never

Current Status: Never entered into force

The START II agreement is sometimes known as the "de-MIRVing" agreement, due to its prohibition of multiple independently targeted reentry vehicles (MIRVs). The United States ratified the original START II text, but did not ratify other agreements that were negotiated at the same time, such as the 1997 Protocol that would have extended the implementation deadline, or the ABM Treaty Succession, Demarcation, or Confidence Building Agreements. ${ }^{51}$ Russia's ratification made the 1997 Protocol and the ABM agreements a requirement before exchanging instruments of ratification, and it was therefore never brought into force. The U.S. Congress did not vote on bringing the complete package into force. ${ }^{52}$

Though the agreement never entered into force, the United States still pursued unilateral disarmament, with the deactivation of the Peacekeeper strategic missile. Deactivation of the Peacekeepers was completed in September 2005. ${ }^{53}$ However, START II can still be considered a success as it drove significant effort into verifiable nuclear warhead dismantlement and chain of custody technology development and demonstrations, which will likely play significant roles in the verification efforts for future disarmament treaties, especially as nuclear weapons limits get very low. ${ }^{54}$

\footnotetext{
${ }^{51}$ Protocol to the Treaty Between the United States of America and the Russian Federation on Further Reduction and Limitation of Strategic Offensive Arms of January 3, 1993 (1997).

52 Arms Control Association (2003) START II and Its Extension Protocol at a Glance. Daryl Kimball, January 2003, www.armscontrol.org/factsheets/start2, accessed 14 November 2012.

${ }^{53}$ U.S. Air Force (2005), Peacekeeper missile mission ends during ceremony, 20 September 2005. www.af.mil/news/story.asp?storyID=123011845, accessed 15 November 2012.

${ }^{54}$ Sohn and Undem, op. cit.
} 


\section{Limitations and Implementation}

Article I of the treaty limited each party to between 3800 and 4250 warheads attributed to deployed ICBMs, SLBMs and heavy bombers, to be achieved no later than December 31, 2004, within the following limitations:

- No more than 2160 warheads attributed to deployed SLBMs;

- No more than 1200 warheads attributed to deployed ICBMs to which more than one warhead is attributed;

- No more than 650 warheads for deployed heavy ICBMS.

Then by January 1, 2003, the aggregate number should be between 3000 and 3500 such that no party has more than $1700-1750$ warheads attributable to deployed SLBMs, zero warheads attributed to deployed ICBM for which more than one warhead is attributable, and zero warheads attributed to deployed heavy ICBMs. Implementation dates were later modified by the 1997 Protocol, which the United States did not ratify. As such, original dates are listed.

Article II required that by January 1, 2003, all ICBM launchers to which multiple warheads were attributed are converted to the type of which only one warhead is attributed. Elimination and conversion should follow START specifications. In addition, the Protocol on Procedures Governing Elimination provided procedures on how to carry out eliminations of items covered under the treaty, and inspections of those eliminations, and conversions of silo launchers ${ }^{55}$

\section{Verification and Monitoring}

The treaty followed START I procedures for inspections, elimination and conversion protocol, memorandum of attribution, and was to remain in force as long as START was in force. ${ }^{56}$ The Protocol on Exhibitions and Inspections ${ }^{57}$ provided for additional verification requirements, and described rules for exhibitions and inspections - e.g. defined roles, rights, responsibilities, and actions to be taken.

The Memorandum of Understanding on Warhead Attribution and Heavy Bomber Data ${ }^{58}$ provided a baseline for warheads attributed to heavy bombers, as well as heavy bombers that have been converted to conventional use, or those that have been transferred back to nuclear, and those with reduced numbers of attributed warheads.

\subsection{SORT (2002)}

Long Name: Treaty Between the United States of America and the Russian Federation on Strategic Offensive Reductions (also known as the Moscow Treaty)

\footnotetext{
${ }^{55}$ Protocol on Procedures Governing Elimination of Heavy ICBMs and on Procedures Governing Conversion of Silo Launchers of Heavy ICBMs Relating to the Treaty Between the United States of America and the Russian Federation on Further Reduction and Limitation of Strategic Offensive Arms (1993).

${ }^{56}$ START II (1993), Article V.

${ }^{57}$ Protocol on Exhibitions and Inspections of Heavy Bombers Relating to the Treaty Between the United States of America and the Russian Federation on Further Reduction and Limitation of Strategic Offensive Arms (1993).

${ }^{58}$ Memorandum of Understanding on Warhead Attribution and Heavy Bomber Data Relating to the Treaty Between the United States of America and the Russian Federation on Further Reduction and Limitation of Strategic Offensive Arms (1993).
} 
Signed: May 24, 2002

Entered into Force: June 1, 2003

Current Status: Expired February 5, 2011

Unlike previous treaties, with significant portions of text devoted definitions, details on counting and rules and specifications of makeup of nuclear strategic forces, the Strategic Offensive Reductions Treaty (SORT) is merely a few paragraphs long. It does not define the make-up of strategic forces, and does not implement any verification regime. Edward Ifft points out that SORT was only two pages long, and took only a few hours to negotiate compared to the START treaty which was 1,000 pages long and took nine years to negotiate.$^{59}$ In fact, United States President George Bush's Letter of Transmittal to the US Senate is longer than the treaty text itself. ${ }^{60}$ The letter reflects a new approach to Russia:

"The U.S. military has put Cold War practices behind it, and now plans, sizes, and sustains its forces in recognition that Russia is not an enemy, Russia is a friend. Militaryto-military and intelligence exchanges are well established and growing.

The Moscow Treaty reflects this new relationship with Russia. Under it, each Party retains the flexibility to determine for itself the composition and structure of its strategic offensive arms, and how reductions are made. This flexibility allows each Party to determine how best to respond to future security challenges.

There is no longer the need to narrowly regulate every step we each take, as did Cold War treaties founded on mutual suspicion and an adversarial relationship."

Unlike other treaties, there was no verification means established, or even mentioned. There were no strict rules regarding the structure of each country's nuclear arsenal, or how it should be counted. The only additional measure brought up by the treaty is that the participants should establish a Bilateral Implementation Commission to meet twice yearly, and that each party can withdraw with three months' notice, but without any requirement for proving the need for national security or other reasons.

\section{Limitations, reductions, and eliminations}

Under Article I of the treaty, each party was to reduce their aggregate number of strategic nuclear warheads so that did not exceed 1,700 to 2,200 warheads each. Unlike in previous treaties on strategic warhead reductions, the composition and structure of the remaining arsenal was at the discretion of each party.

\section{Implementation}

\footnotetext{
${ }^{59}$ Ifft, Edward (2010) "Political Dimensions of Determining 'Effective' Verification” in Corey Hinderstein (ed.) Cultivating Confidence. Verification, Monitoring, and Enforcement for a World Free of Nuclear Weapons, Hoover Institution Press, Stanford, California.

60 "Letter of Transmittal" The White House, June 20, 2002.
} 
Under SORT, force structures, deployments, and other characteristics were left up to each country. Under Article I, each party would "determine for itself the composition and structure of its strategic offensive arms, based on the established aggregate limit for the number of such warheads. ${ }^{" 11}$ In case of any disagreements or questions regarding the implementation of the SORT, Article III established a Bilateral Implementation Committee, which was to meet twice per year.

Verification and Monitoring

SORT did not mention verification mechanisms.

\subsection{New START (2010)}

Long Name: The Treaty Between the United States of America and the Russian Federation on Measures for the Further Reduction and Limitation of Strategic Offensive Arms

Signed: April 8, 2010

Entered into force: February 5, $2011^{62}$

Current Status: In force until February 4, 2021, with possible five year extension

Under New START, Russia and the United States agree to reduce to 1,500 deployed nuclear warheads; 800 deployed and non-deployed strategic launchers and heavy bombers; and 700 deployed strategic launchers and heavy bombers within seven years of entry into force of the treaty.

Graham Allison of the Belfer Center for Science and International Affairs describes the New START as returning to "the mainstream of superpower arms control" and "Leaving behind President George W. Bush's unilateralism, this give-and-take agreement mirrors earlier treaties of George H.W. Bush and Ronald Reagan. ${ }^{\circ 3}$ According to Allison, the New START shows each state's commitment towards fulfilling its NPT obligation for ultimate nuclear weapons elimination, by bringing nuclear weapons levels down 30\% from the upper limits of the SORT agreement and "almost 90 percent below the high" at the peak of the Cold War. ${ }^{64}$

\section{Limitations and Implementation}

Under Article II of the treaty, each party will reduce its armaments to the levels of:

- 700 deployed ICBMs, deployed SLBMs, and deployed heavy bombers;

- 1550 warheads in deployed ICBMs, deployed SLBMs, and deployed heavy bombers; and

- 800 deployed and non-deployed ICBM launchers, SLBM launchers, and heavy bombers,

\footnotetext{
${ }^{61}$ SORT (2002), Art. I.

${ }^{62}$ U.S. Department of State, New START Entry Into Force, www.state.gov/r/pa/prs/ps/2011/02/156037.htm, accessed 2012-10-29

${ }^{63}$ Allison, Graham (2010), "How Significant a new START for the U.S. and Russia?" Washington Post, 09 April 2010. www.washingtonpost.com/wp-dyn/content/article/2010/04/08/AR2010040803424.html, accessed 19 November 2012.

${ }^{64} \mathrm{Id}$.
} 
Under Article $\mathrm{V}$ of the treaty, modernization and replacement of strategic offensive arms is permitted, subject to provisions within treaty. New strategic weapons types can be considered by the bilateral consultative commissions. Reductions are to be made within seven years of the treaty's entry into force.

New START takes a new approach on how it deals with force levels, rather than counting "attributable warheads", New START counts treaty items "as deployed." The Union of Concerned Scientists explains the difference succinctly:

Previous arms control treaties estimated the number of deployed warheads each nation had by counting each missile as carrying its maximum possible load. New START instead counts the actual number of warheads on each missile, giving a much more accurate assessment of the size of the deployed arsenals of the two countries. Heavy bombers are counted towards the warhead limit as one warhead for each bomber, regardless of that bomber's actual capacity. This counting rule reflects the relatively stabilizing nature of bombers, which are not a first-strike delivery system, in the U.S.-Russian strategic relationship. ${ }^{65}$

\section{Verification and Monitoring}

New START continues the tradition of START I with threefold verification activities: NTM, onsite inspections, and exchanges of data including telemetric information. Article $\mathrm{X}$ defines the verification measures allowed under New START. As with previous disarmament treaties, NTM shall be used for verification and states are prohibited from using concealment measures.

Article XI provides for on-site inspections to "confirm the accuracy of declared data on the numbers, types, and technical characteristics of non-deployed strategic offensive arms" and to confirm conversions or eliminations. Facilities subject to inspection are listed in Section VII of Part Five of the Protocol to the New START. The Annex on Inspection Activities ${ }^{66}$ provides additional details regarding the conduction of on-site inspections.

Under Article IX, the parties are to exchange telemetric data regarding launches of ICBMs and SLBMs. Section 8 of the Protocol and the Annex on Telemetric Information ${ }^{67}$ provides much more detail on requirements for the provision of telemetric information. Information shall also be exchanged regarding conversions, eliminations, or movements. ${ }^{68}$ Additional details on provision of notification can be found in the Annex on Notifications. ${ }^{69}$

\footnotetext{
${ }^{65}$ Union of Concerned Scientists (2011), "New START Overview (2011)" 26 May 2011. www.ucsusa.org/nuclear_weapons_and_global_security/nuclear_weapons/policy_issues/new-start-general-factsheet.html, accessed 19 November 2012.

${ }^{66}$ Annex on Inspection Activities to the Protocol to the Treaty Between the United States of America and the Russian Federation on Measures for the Further Reduction and Limitation of Strategic Offensive Arms

${ }^{67}$ Annex on Telemetric Information to the Protocol to the Treaty Between the United States of America and the Russian Federation on Measures for the Further Reduction and Limitation of Strategic Offensive Arms

${ }^{68}$ See Article IV, para. 11, Article VI, and Article VII.

69 Annex on Notifications to the Protocol to the Treaty Between the United States of America and the Russian Federation of Measures for the Further Reduction and Limitation of Strategic Offensive Arms
} 
The New START has been heralded as a highly successful nuclear disarmament treaty thus far. The status of New START arms reductions, as of Sep 1, 2012, is shown in the chart below:

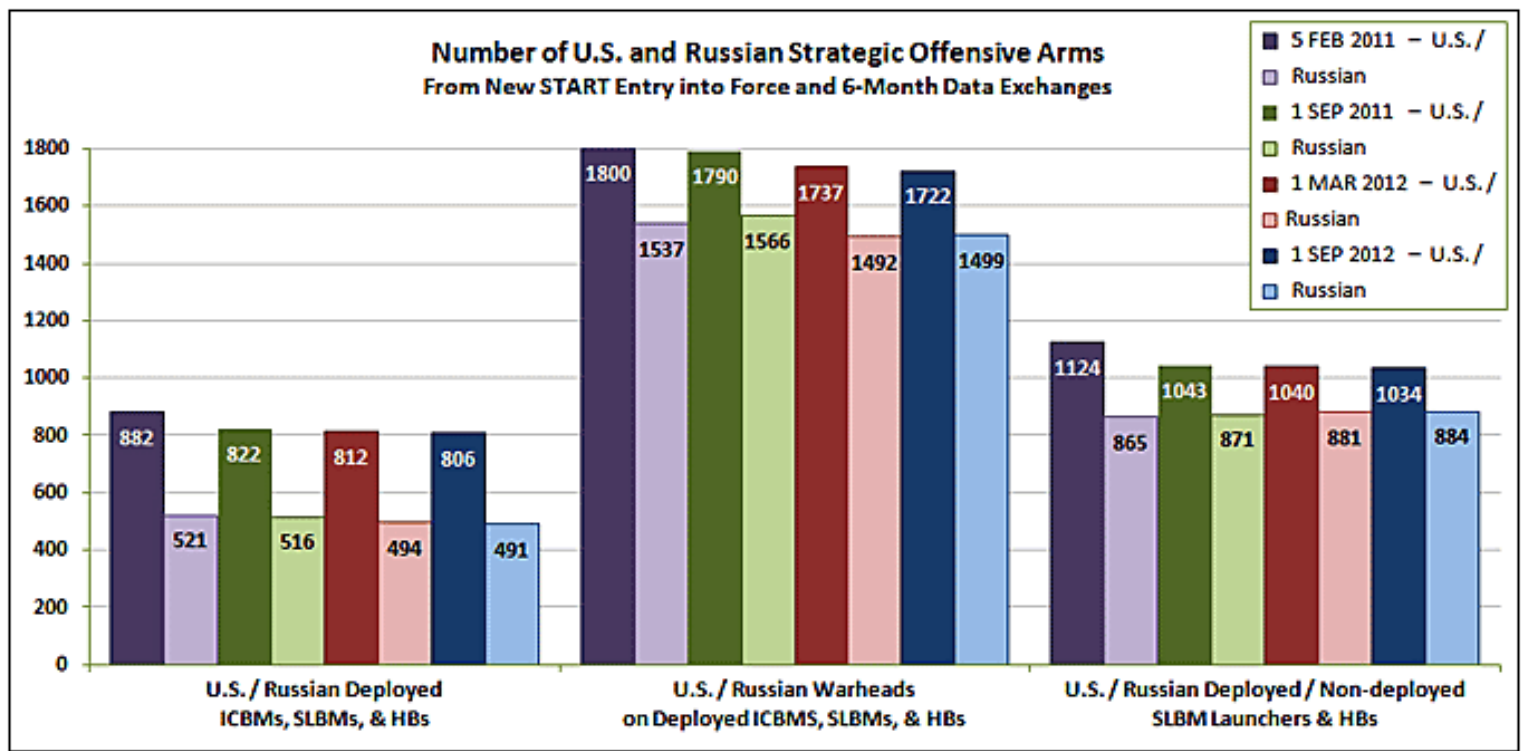

Figure 3 Number of U.S. and Russian Stratgic Offensive Arms: From New START Entry into Force and 6-Month Data Exchanges ${ }^{70}$

\subsection{International Legal Framework for Denuclearization}

This section will describe the denuclearization agreements signed by the United States and Russia. The denuclearization efforts taken by the United States and Russia can be seen as additional confidence building measures between the two states, in addition to their disarmament agreements. By disabling mechanisms to create additional fissile materials for nuclear weapons use, or disposing of excess military materials such as highly enriched uranium (HEU) or plutonium, both sides are working to assure that nuclear disarmament treaties are not reneged, and reduce the risk of theft from large inventories of unneeded weapons useable materials.

As with nuclear disarmament, the only current framework for denuclearization as defined in the introduction is through bilateral agreements between the United States and Russia.

\subsection{Highly Enriched Uranium Purchase Agreement (1993)}

Long Name: The Russian-U.S. Agreement Concerning the Disposition of Highly Enriched Uranium Extracted from Nuclear Weapons

Signed: February 18, 1993

Entered into force: February 18, 1993

Current status: In force, set to expire February 18, 2013

\footnotetext{
${ }^{70}$ Defense Treaty Inspection Readiness Program (2012), http://dtirp.dtra.mil/NC/nc_References/weapons.aspx, accessed 13 November 2012.
} 
The Highly Enriched Uranium (HEU) Purchase Agreement seeks to transform weapons-useable material into material that does not have direct weapons use. Under the HEU Purchase Agreement, the United States monitors the conversion of Russian HEU into low-enriched uranium (LEU), which the United States then buys for use in its civilian nuclear reactors. ${ }^{71}$ The HEU Purchase Agreement expires in 2013, and will have confirmed that 500 metric tons of HEU (averaging over $90 \%$ enriched) was eliminated from the Russian stockpile. ${ }^{72}$

The agreement was to remain in force "for twenty years until the full amount of HEU provided for in paragraph 1 of Article I is converted to LEU, delivered, and supplied to commercial customers." ${ }^{, 73}$ The program has resulted in a government-industry partnership, where industry partners, not the states themselves actually execute the scope specified in the agreement. In the United States, the United States Enrichment Corporation (USEC) acts as the "executive agent" and in Russia, it is Techsnabexport (TENEX). The first shipment of down-blended Russian uranium arrived in United States June 1995, and since then up to $10 \%$ of U.S. electricity has been produced per year from the agreement. ${ }^{74}$ Due to the link between weapons-useable materials and civilian nuclear energy production, this agreement is sometimes referred to as Megatons to Megawatts.

\section{Limitations and Implementation}

Article I of the agreement calls for the conversion of 500 metric tons of Russian HEU to LEU. Under Article II, contracts (with industry) shall provide for details and time tables for conversions. Those contracts are between the USEC and TENEX.

\section{Verification and Monitoring}

Under Article V of the HEU Agreement, the HEU and LEU acquired by the United States under the agreement is subject to IAEA safeguards. While the treaty does not call for specific verification measures besides the implementation of IAEA safeguards, Article V does require the parties to "establish transparency measures to ensure objectives of this Agreement are met," which include access to materials control and accounting.

\subsection{Plutonium Production Reactor Agreement (1997)}

\section{Long Name: The Agreement between the Government of the United States of America and the} Government of the Russian Federation Concerning Cooperation Regarding Plutonium

Production Reactors.

Signed: September 23, 1997

Entered into Force: September 23, 1997

\footnotetext{
${ }^{71}$ NNSA, Highly Enriched Uranium Disposition. http://nnsa.energy.gov/aboutus/ourprograms/nonproliferation/materialremovaldisposition/highlyenricheduraniumdis position, accessed 30 October 2012.

${ }^{72}$ Id.

${ }^{73}$ HEU Purchase Agreement (1993), Art. VI, para. 1.

${ }^{74}$ United States Enrichment Corporation, Megatons to Megawatts. www.usec.com/russian-contracts/megatonsmegawatts, accessed 30 October 2012.
} 
Current Status: In force until one year after written notice from either party

The purpose of the Plutonium Production Reactor Agreement (PPRA) is to cease operations of plutonium production reactors feeding the governments' nuclear weapons programs, to "prevent the accumulation of excessive stocks of plutonium and reduce them in the future." 75 Plutonium production reactors are to be shut down, or converted so that operations are geared towards energy production rather than plutonium production.

\section{Limitations and Implementation}

Under the PPRA, by December 31, 2000 the plutonium producing reactors listed in Annex I of the treaty were to have undergone modifications so that the reactors are no longer producing "non-reactor-grade" plutonium, and will eventually cease operation at the end of their normal lifetimes. ${ }^{76}$ Plutonium production reactors that had already been shut down were to remain shut down. Russian shutdown reactors that were not to resume operation included: ${ }^{77}$

- Ozersk

- A Reactor

- IR-AI Reactor

- AV-1 Reactor

- AV-2 Reactor

- AV-3 Reactor

- Zheleznogorsk

- AD Reactor

- ADE-1 Reactor

- Seversk

- I-1 Reactor

- I-2 Reactor

- ADE-3 Reactor

In the United States, shutdown reactors that were not to resume operations included: ${ }^{78}$

- Hanford

- B, C, D, DR, F, H, KE, KW, and N Reactors

- Savannah River

- K, L, P, R, and C Reactors

Operating plutonium production reactors in Russia that would undergo conversion included:

- Zheleznogorsk

- ADE-2 Reactor

- Seversk

\footnotetext{
${ }^{75}$ PPRA (1997), Preamble.

${ }^{76}$ Id., Article I.

${ }^{77}$ Id., Annex I.

${ }^{78}$ Id., Annex II.
} 
- ADE-4 Reactor

- ADE-S Reactor

There were no operating plutonium production reactors in the United States at the time of the agreement. In addition to governing the operation of plutonium producing reactors, under Article IV of the agreement, plutonium produced in specified reactors after the agreement's entry into force shall not be used in nuclear weapons.

The PPRA does not make any additional requirements on the structure of a country's production capabilities (i.e., uranium production or weaponization capabilities). The scope of the PPRA is only related to plutonium production reactors. In the agreement's annexes, it lists all of the reactors that fall under the treaty. All reactors must either be non-operational, or have had modifications so they were no longer producing "non-reactor grade" plutonium, by 2001.

\section{Verification and Monitoring}

Under Article I, monitoring shall occur to ensure that shut down reactors remain so, to ensure that any plutonium produced in those reactors is not used for nuclear weapons, and that once modified, the reactors operate only in the modified mode, that is to say, they do not return to plutonium production activities. Annex III of the agreement deals with monitoring activities. Under Articles II and IV of Annex III, processes, procedures, and equipment for monitoring activities are defined. Annexes I and II also support verification activities. Annex I provides a shutdown reactor list, while Annex II contains a list of those that were operating at the time of signature.

\subsection{Plutonium Management and Disposition Agreement (2000)}

\section{Long Name: Agreement Between the Government of The United States of America and the} Government of The Russian Federation Concerning the Management and Disposition of Plutonium Designated as no Longer Required for Defense Purposes and Related Cooperation. Signed: (announced) June 4, 2000. ${ }^{79}$ Amendment signed April 13, 2010 Entered into force: July 13, $2011^{80}$

Current Status: Will remain in force until each party has disposed of at least 34 metric tons of plutonium

The Plutonium Management and Disposition Agreement (PMDA) aims to make arms reductions irreversible by disposing of excess to defense weapons grade plutonium and prohibiting it from future weapons use. The United States is pursuing its disposition requirements through fabrication of mixed-oxide (MOX) fuel, which requires blending of plutonium with uranium oxide, and irradiating the MOX fuel in light water reactors, thereby rendering it unusable for weapons use. To support that effort, the United States is constructing a MOX fuel fabrication

\footnotetext{
${ }^{79}$ Defense Treaty Inspection Readiness Program, Treaty Information Center. http://dtirp.dtra.mil/tic/implementation_status.aspx, accessed 16 November 2012.

${ }^{80}$ Defense Treaty Inspection Readiness Program, Plutonium Management and Disposition Agreement (PMDA) http://dtirp.dtra.mil/TIC/synopses/pmda.aspx, accessed 30 October 2012.
} 
plant at the Savannah River Site near Aiken, South Carolina. The United States broke ground for the plant on August 1, 2007, and as of February 2011 operations at the plant were scheduled to begin in $2016 .^{81}$ Both parties expect to begin disposition activities by $2018 .^{82}$

\section{Limitations and Implementation}

In the PMDA, each party agrees to "dispose" of at least 34 metric tons of weapon-grade plutonium that is no longer needed for defense purposes. ${ }^{83}$

Under Article III, the excess plutonium shall be disposed of through irradiation as fuel in a nuclear reactor, immobilization, or through another method agreed upon in writing. (This was updated, however, in the 2010 Protocol to the Treaty to remove "immobilized forms" from disposition methods. ${ }^{84}$ ) Under Article IV, each party will dispose of "no less than" two metric tons plutonium per year. In addition, under Article V, upon entry into force of the agreement the parties will establish an action plan to at least double the disposition rate. In the 2010 Protocol, the disposition amount was modified to 1.3 metrics tons per year, with each party seeking to increase the disposition rate "to the extent practicable." ${ }^{85}$ The modification was made in order to align the treaty text more closely to the rate at which the Russian reactors could transmute the material. ${ }^{86}$

In accordance with the agreement's denuclearization goals, any plutonium designated as "disposition plutonium" under the agreement shall not be used for any military purpose by the state (including for manufacture, design, testing, etc. of a nuclear weapon), or transferred to a third country except as agreed upon in writing, and under terms provided for in the agreement, including the Convention on the Physical Protection of Nuclear Material (1987) ${ }^{87}$ Furthermore, neither party will separate plutonium from spent fuel until they have attained the 34 metric tons specific in Article II, and will not separate "disposed" plutonium from immobilized forms. ${ }^{88}$ When immobilization was removed from disposition methods in 2010, the language of Article VI was updated accordingly. ${ }^{89}$

\footnotetext{
${ }^{81}$ NNSA (2011), NNSA's MOX Fuel Fabrication Facility and U.S. Plutonium Disposition Program, 14 February $2011 \mathrm{http}: / /$ nnsa.energy.gov/mediaroom/factsheets/mox, accessed 30 October 2012.

82 Defense Treaty Inspection Readiness Program, Plutonium Management and Disposition Agreement (PMDA) http://dtirp.dtra.mil/TIC/synopses/pmda.aspx, accessed 30 October 2012.

${ }^{83}$ PMDA (2000), Article II.

${ }^{84}$ Protocol to the PMDA (2010), Article I.

${ }^{85}$ Id.

${ }^{86}$ Horner, D (2010), “Russia, U.S. Sign Plutonium Disposition Pact.” Arms Control Today, May 2010. www.armscontrol.org/print/4212, accessed 15 November 2012.

${ }^{87}$ PMDA (2000), Article VI.

${ }^{88}$ Id., para. 2.

${ }^{89}$ Protocol to the Agreement between the Government of the United States of America and the Government of the Russian Federation Concerning the Management and Disposition of Plutonium Designated as No Longer Required for Defense Purposes and Related Cooperation (2010), Article I.
} 
Under Article IX, the United States will make up to $\$ 200$ million available for plutonium disposition activities in Russia. In the 2010 protocol, this amount was amended to $\$ 400$ million. ${ }^{90}$

\section{Verification and Monitoring}

The treaty requires monitoring and verification of "dispositioned" plutonium. In August 2010 the United States and Russia requested consultations with the IAEA on an agreement whereby it would monitor the disposition and conduct independent verification measures. As of July 2012, negotiations regarding the involvement of the IAEA remained in-progress. ${ }^{91}$

\subsection{Prospects for Future Agreements}

Historical and current nuclear disarmament and denuclearization agreements have set a strong precedent for bilateral cooperation for the reduction of nuclear weapons, their delivery systems, and their production materials and facilities. There is existing legal framework for a wide array of limitations, reductions, and eliminations spanning from temporary freezes in development, or deactivation of facilities, to complete destruction of an entire class of weapon, and disposal or conversion of key materials. Likewise, implementation measures have varied from ambitious, phased timelines with defined force structures, to more lax guidelines in which states are required to meet the goals of the treaty or agreement in the way they see fit, as long as it is complete by the specified deadline. Verification regimes have spanned from NTM as the sole source of information, to intrusive on-site inspections, exhibitions, and broadcasting of telemetric information.

The majority of nuclear disarmament and denuclearization treaties reached between the United States and Russia have been progressively more demanding - with heftier reductions, and more intrusive verification regimes. Future arrangements between Russia and the United States are likely to continue in that direction. However, it must be recognized that historical treaties and agreements have not been negotiated in a vacuum, and the state of science and technology, as well as the international political and security climate, will drastically impact what is feasible in future negotiations for international nuclear disarmament treaties.

Future agreements will likely involve additional partners. Previous nuclear disarmament and denuclearization treaties and agreements were concluded exclusively between the United States and Russia (or the former USSR and the resulting states that had nuclear capability) as these parties had the largest arsenals. However, as numbers of nuclear weapons decrease, approaching the levels of other nuclear-armed states, it will likely be necessary to involve those states in negotiations. Henry Kissinger and Brent Scowcroft, in the April 2012 opinion editorial piece in the Washington Post, say that the United States and Russia have a "special responsibility" to decrease their nuclear arsenals, as the two most nuclear armed countries in the world (by an

\footnotetext{
${ }^{90} \mathrm{Id}$.

${ }^{91}$ Defense Treaty Inspection Readiness Program, Plutonium Management and Disposition Agreement (PMDA) http://dtirp.dtra.mil/TIC/synopses/pmda.aspx, accessed 30 October 2012.
} 
order of magnitude at least). They argue that "other countries need to be brought into the discussion when substantial reductions from existing START levels are on the international agenda." ${ }^{92}$ Engagement activities between the United Kingdom and Norway suggest that there may be an opportunity to meaningfully engage NNWS in the process as well. The involvement of NNWS in future negotiations and agreements will likely drive greater intrusiveness in verification to prove NWS are abiding by treaty requirements. At the same time, including NNWS will limit the openness of the regimes for fear of transferring nuclear weapons knowledge, and thereby violating NPT Article I requirements on the transfer of nuclear weapons information.

Just as with historical and current nuclear disarmament and denuclearization agreements, there are three organizing principles around which possibilities for future engagements or reductions must be considered: limitations, reductions and eliminations; implementation; and verification and monitoring. This section will explore each in turn.

\subsection{Prospects for Future Nuclear Disarmament}

The world's latest nuclear disarmament treaty - New START - has a relatively short lifespan of ten to fifteen years. Policy makers in Russia and the United States are likely already considering a "Next START" agreement, or even subsequent agreements. A future nuclear disarmament treaty will likely follow existing arms limitation and reduction principles based on previous agreements - incremental cuts in the nuclear arsenals of the United States and Russia, with increasingly intrusive verification regimes.

Future negotiations involving other nuclear-armed states will have to consider how multilateralization will impact discussions. While the United States and Russia have established a history of engagement and trust, that relationship will have to be developed over time with other states.

\subsubsection{Limitations and Implementation}

Limitations, reductions, and eliminations for nuclear disarmament will likely continue in incremental steps. The United States and Russia will continue with their bilateral framework, and will eventually broaden negotiations to engage other NPT NWS. Multilateral negotiations for arms reductions will likely be concluded first within the NPT NWS, and establish the first attempt at multilateral nuclear disarmament before discussions can begin with nuclear-armed states outside of the NPT.

In the future, one could foresee a total aggregate number allotment (including strategic and nonstrategic nuclear weapons). An alternative possibility for implementing future agreements could be incremental reductions, i.e. all states would agree to cut their arsenals by $10 \%$. Reducing

\footnotetext{
${ }^{92}$ Kissinger, H. and B. Scowcroft (2012), "Nuclear Weapons Reduction Must be Part of Strategic Analysis." Washington Post, 23 April 2012.
} 
inventories to zero is not a near-term goal. It will be necessary to build on previous mechanisms of phased reductions and eliminations.

James Doyle describes some of the possible types of reductions or limits that would be possible under future nuclear disarmament treaties: ${ }^{93}$

- Reduce deployed strategic warheads, strategic delivery vehicles and launchers below the limits required by START.

- Reduce non-strategic nuclear warheads.

- Reduce non-deployed strategic warheads.

- Establish a single limit covering all nuclear warheads - providing freedom to mix strategic and nonstrategic, deployed and non-deployed - perhaps with one or two sublimits, e.g., a sub-limit on deployed strategic warheads.

- Require that some specified number of warheads remain in permanently monitored storage.

\section{Strategic and Non-Strategic}

Most nuclear disarmament treaties deal with force specifications - that is, what is the structure of a party's nuclear arsenal (how many of different kinds of weapons), where is it kept, how it is stored, or moved, or upgraded, etc. Future nuclear disarmament agreements will likely have to deal with both non-strategic and strategic nuclear forces. Non-strategic weapons have historically been of less concern in the nuclear disarmament realm, but the close proximity of some states that will likely be involved in future agreements, such as those in Europe, will likely bring more attention to the issue of non-strategic disarmament..

Following the conclusion of the New START, the United States said that it was "the goal of the United States to seek further reductions in all types of U.S. and Russian nuclear weapons," including both strategic and nonstrategic. ${ }^{94}$ This will be especially significant given Russia's assumed advantage over the United States in non-strategic nuclear weapons. ${ }^{95}$ Mark Stout argues that there is a broader nonproliferation implication of limiting non-strategic nuclear weapons, beyond bilateral disarmament considerations:

"[The] world should consider the fact that non-strategic nuclear weapons pose a much greater danger than their strategic counterparts. This is because they are more vulnerable to nonauthorized use, including theft, than strategic weapons, which almost always have dedicated delivery vehicles, better physical security, and better-established and mature methods and procedures. Additionally, because non-strategic nuclear weapons tend to have lower yields

\footnotetext{
${ }^{93}$ Doyle, James (2012), U.S.- Russia Nuclear Arms Reductions: The Next Round, Nuclear Threat Initiative, 25 June 2012.

${ }^{94}$ Kimball, Daryl (2012) "The Presidential Nuclear Initiatives (PNIs) on Tactical Nuclear Weapons at a Glance.” Arms Control Association, August 2012. www.armscontrol.org/factsheets/pniglance, accessed 15 November 2012.

${ }^{95}$ Stout, op. cit.
} 
and are inclined towards "battlefield" use, it can be argued that their inherent nature makes their authorized use more probable." $" 96$

\section{Deployed and Non-Deployed Systems}

Limitations on the deployment of each state's nuclear arsenal will also be a legal challenge that must be met for future nuclear disarmament negotiations. This refers to both deployed and nondeployed weapons within a state, as well as those weapons that are deployed in foreign countries. According to the James Martin Center for Nonproliferation Studies' Jeffrey Lewis, the United States intends to pursue a "whole enchilada" approach to further arms reductions, and will seek an agreement that includes "both non-deployed and deployed nonstrategic nuclear weapons" in the next round of negotiations with Russia. ${ }^{97}$

The U.S. deployment of nuclear weapons in North Atlantic Treaty Organization (NATO) countries is expected to be a significant issue for Russia in future nuclear disarmament treaties. According to Mark Stout, "Russia has staked out an intellectual position that asserts nuclear weapons must remain within a nation's borders. Following this logic, [the United States] provided non-strategic nuclear weapons, under NATO's control, are verboten. ... If NATO rids itself of non-strategic nuclear weapons, Russia would consider its security enhanced by the elimination of these weapons."98

\section{Targeting}

Historical nuclear disarmament treaties have included provisions beyond the number of nuclear warheads or their delivery systems, such as deployment and stationing - where a nuclear weapon is located, how many can be stationed together, or how far apart the bases must be. An additional aspect that might be considered in future nuclear disarmament agreements is the targeting of those weapons, with provisions or prohibitions on targeting nuclear weapons with nuclear or conventional forces. Some policy researchers suggest that prohibiting the targeting of nuclear forces might serve as a confidence building measure between states seeking to multilaterally decrease their nuclear arsenals, and assuage a state's fears of having its entire nuclear arsenal destroyed. ${ }^{99}$ Including targeting as part of a nuclear disarmament treaty would be novel to nuclear disarmament, and would require some additional legal support for how that would be implemented or verified. Missile defense systems might also be discussed along similar lines.

\footnotetext{
${ }^{96} \mathrm{Id}$.

${ }^{97}$ Jeffery Lewis, "Russia and the United States Should Resume Data Exchanges on Nuclear-Armed Sea-Launched Cruise Missiles." Beyond Treaties: Immediate Steps to Reduce Nuclear Dangers. Ed. James M. Acton. Carnegie Endowment for International Peace, October 2012.

${ }^{98}$ Stout, op. cit.

${ }^{99}$ For example, see: Zhao, Tong (2012), "The United States should Commit not to Target Russian or Chinese Nuclear Forces with its Conventional Forces.” In Beyond Treaties: Immediate Steps to Reduce Nuclear Dangers. Ed. James M. Acton. Carnegie Endowment for International Peace, October 2012.
} 


\subsubsection{Verification and Monitoring}

As states begin to reduce their nuclear stockpiles to low levels, there will be increased needs to strengthen verification regimes. There may be specific legal challenges that must be overcome in order to: verify very low numbers of nuclear weapons, multilateralize disarmament verification as a confidence building measure between nuclear weapon and non-nuclear weapons states, and incorporate enhanced verification technologies. Many of the uncertainties surrounding future verification regimes result from an unclear legal framework when expanding the breadth of nuclear disarmament treaties to include nuclear-armed countries besides the United States or Russia, sensitivities surrounding national security information that could be revealed during verification activities (and the progress of technology to allow for more intrusive verification without revealing sensitive details), and the assumed intense verification measures that will be needed as nuclear inventories approach lower numbers.

\section{Verifying Low Numbers}

Deep reductions will require more vigorous verification regimes, rather than delivery systems, or "as deployed" systems as in New START. A future very low number nuclear disarmament agreement will likely require verified dismantlement of nuclear weapons. It is not yet clear if that enhanced verification will include actual inspector witness of warhead dismantlement, intense material accountancy, or some sort of managed access combination of the two. ${ }^{100}$ One significant challenge to verifying low numbers is the difficulty in verifying historical production quantities, especially when aggregate nuclear weapons numbers go so low that production uncertainties begin to equal the amount of fissile material in remaining weapons. It is not yet clear whether or not a proposed Fissile Material Cut-off Treaty (FMCT, discussed in additional detail below) will include provisions on historical production - if it does not cover historical production, some other agreement will have to. Otherwise, states may be hesitant to decrease their stockpiles for fear of hidden stockpiles of historically produced material in other states which could rapidly be converted to weapons use.

Verification of small inventories will require increased data exchange and transparency between states to provide confidence that all nuclear weapons in a state have been accounted for. James Doyle states that the "most critical information to exchange" to facilitate negotiations for "reducing any or all categories of nuclear weapons" in the near term should include: ${ }^{101}$

- Deployed strategic

- Non-deployed strategic

- Non-strategic

- Retired and awaiting dismantlement

\footnotetext{
${ }^{100}$ Bowen, Wyn Q. and Andreas Persbo (2009), How Might States, or the International Community, go about Implementing the Dismantlement of Nuclear Weapons Systems in an Accurate Way which would Engender International Confidence, International Commission on Nuclear Non-Proliferation and Disarmament, February 2009.

${ }^{101}$ Doyle, op. cit.
} 
Other bilateral confidence building measures that could provide a basis for future verification regimes include bilateral visits to nuclear weapon storage facilities, visits to warhead assembly and disassembly sites, and joint demonstrations of dismantlement verification technologies. ${ }^{102}$

\section{Multilateral Verification}

According to Bowen and Persbo, the "sheer scale of challenges and the political significance of moving towards a nuclear weapons free world...may necessitate the establishment of a new multilateral verification [organization]." 103 The authors say that nuclear disarmament "is expected...to turn into a multilateral effort, as numbers get closer to zero. In addition, nonnuclear weapons states may require more transparency in the dismantlement process, necessitating the involvement of non-nuclear weapon state inspectors under the guidance of a multilateral verification authority." ${ }^{104}$

The IAEA's Statute allows it to provide safeguards at the request of parties to "establish and administer safeguards designed to ensure that special fissionable and other materials, services, equipment, facilities, and information made available by the Agency or at its request or under its supervision or control are not used in such a way as to further any military purpose; and to apply safeguards, at the request of the parties, to any bilateral or multilateral arrangement, or at the request of a state, to any of that state's activities in the field of atomic energy." 105 The ability of the IAEA to participate in verification of nuclear weapons origin material was researched under the U.S., Russian, IAEA “Trilateral Initiative" between 1996 and 2002. ${ }^{106}$ Though the Joint Working Group to the Trilateral Initiative made significant technical progress during its six years of cooperation, the political drive to actually implement a verification agreement under the Trilateral Initiative was not there. ${ }^{107}$

Bowen and Persbo argue that a multilateral verification body, separate but cooperative with the IAEA, would have the advantage of a "singular focus" rather than juggling the promotion and verification of civilian nuclear applications. In addition, the authors promote the involvement of NNWS in a multilateral verification body, which could potentially offer technical expertise as well as build confidence in the disarmament process. ${ }^{108}$

\section{Enhanced Verification Technologies}

One area of concern regarding the verification of disarmament of nuclear warheads is how to conduct those verification activities without exposing sensitive proliferation or national security information. This necessitates a mechanism by which actual nuclear material coming from

\footnotetext{
${ }^{102}$ Id.

${ }^{103}$ Bowen and Persbo, op. cit.

104 Id., pp. 17.

${ }^{105}$ Statute of the IAEA (1956). Article III, para. 5.

${ }^{106}$ See: Shea, Tomas (2001) "Report on the Trilateral Initiative: IAEA Verification of Weapon-Origin Material in the Russian Federation and the United States" IAEA Bulletin, 43/4/2001.

www.iaea.org/Publications/Magazines/Bulletin/Bull434/article9.pdf, accessed 10 November 2012.

${ }^{107}$ Shea, Thomas (2008), “The Trilateral Initiative: A Model for the Future?” Arms Control Today, May 2008.

${ }^{108}$ Bowen and Persb, op. cit., pp. 14
} 
nuclear warheads can be verified in an unclassified way, so that the process can be more transparent for partners. One solution that has been investigated by several bodies interested in nuclear disarmament is an information barrier which would include "procedures and technology that prevent the release of sensitive information during a joint inspection of a sensitive nuclear item, and provides confidence that the measurement system into which it has been integrated functions exactly as designed and constructed." ${ }^{109}$ This approach is designed to reveal just enough information to ensure treaty compliance, without exposing classified information to inspecting parties." In a measurement system, all the data is measured or collected, but only agreed-upon, unclassified data is released through the information barrier. An additional consideration for an information barrier, besides nuclear weapon states seeking to protect their classified information, is the commitment under the NPT (1968) Article I, that NWS will not "assist, encourage, or induce" a NNWS to manufacture a nuclear weapon. NWS will need to assure that information shared with NNWS in the process of disarmament verification could not be considered nuclear weapon development assistance. ${ }^{110}$

As technologies that can be used for verification measures expand, the legal framework will have to be considered for how to incorporate information from these technologies. U.S. Acting Under Secretary for Arms Control and International Security Rose Gottemoeller has advocated the use of alternatives to traditional verification technologies, including those based on social media (the tools, techniques, and technologies that use the internet to facilitate communication in an open environment). In March 2012, Gottemoeller proposed that social media could support arms control verification in two ways: as an active task and for deep analysis. As an active task, which she calls a "public verification challenge," countries could engage the public as a confidence building measure to support the conclusion that, for example, "it was not stashing extra missiles in the woods... or a fissile material production reactor in the desert."111

As deep analysis, Gottemoeller poses the use of existing, open source social media data to "understand where strange effluents are flowing, to recognize patterns of industrial activity, to queue sensors and satellites. Such queuing could help us to make better use of our scarce and expensive National Technical Means, or in some cases to supplement them in important ways." 112 Though the use of social media will never be able to supplant the use of other verification technologies, it could be used to supplement traditional verification techniques. ${ }^{113}$

\footnotetext{
${ }^{109}$ Fuller, J.L. and J.K. Wolford (2001), Information Barriers, Presented at the 2001 Symposium on International Safeguards: Verification and Nuclear Material Security, International Atomic Energy Agency, Vienna, Austria, 29 October - 02 November 2001. www-pub.iaea.org/MTCD/publications/PDF/ss2001/PDF\%20files/Session\%2017/Paper\%2017-01.pdf, accessed 21 November 2012

${ }^{110}$ Persbo, Andreas and Marius Bjørningstad (2008), "Verifying Nuclear Disarmament: The Inspector's Agenda," Arms Control Today, May 2008.

${ }^{111}$ Gottemoeller, Rose (2012), Arms Control in the Information Age, Remarks by Rose Gottemoeller at the Moscow State Institute of International Relations, Moscow, Russia, 30 March 2012.

112 Id.

113 See: Kreyling, Sean, Laura Schmidt Williams, Zoe Gastelum, Kevin Whattam, Court Corley, Nick Cramer, Stuart Rose, Eric Bell, and Michelle Gregory (2012), Use of Social Media to Target Information-Driven Arms
} 


\subsection{Prospects for Future Denuclearization Agreements}

The HEU Purchase Agreement (1993) has almost expired, and the PMDA (2000) will be coming online in the next few years with the eventual disposal of 68 metric tons of excess plutonium between Russia and the United States. If a future arms control agreement will incorporate denuclearization, such an agreement might consider a reduction not just in weapons-useable nuclear material but also reductions of certain types of nuclear facilities, like was done in the Plutonium Production Reactor Agreement.

\subsubsection{Limitations and Implementation}

Near-term denuclearization agreements will likely follow the current pattern of disposal or conversion of excess fissile materials, in continuation of goals met under the HEU Purchase Agreement or the PMDA. Other agreements could potentially convert or shut-down militaryspecific facilities which are no longer needed or have naturally come to the end of their lifetimes.

Further reductions in military materials stockpiles could be approached through the negotiation of a FMCT, in which NPT NWS would agree to halt production of fissile materials for use in nuclear explosive devices (NNWS have already agreed not to produce fissile materials for nuclear explosive devices and have IAEA safeguards agreements to verify this). Negotiations of a FMCT have been stalled for decades within the United Nations' Conference in Disarmament. According to the Nuclear Threat Initiative, the disagreements stem from two issues: whether a treaty would cover existing stocks of fissile materials, and verification regimes. ${ }^{114}$

In the denuclearization realm, there will likely be a spread of stops or modifications to some technologies, such as to the plutonium production reactors. There could also be similar agreements related to the refurbishment, modification, or shutting down of weaponization facilities, or modifications or destruction of certain components. The aging infrastructure of the NW complex in the United States, Russia, and other NPT NWS could make this easy, as they might soon cease operations anyway.

Future denuclearization treaties will likely include additional reductions to the nuclear weapons infrastructure of NWS. It might include the shutdown of nuclear armament production or maintenance facilities, or specialized manufacturing plants. This will have to be completed in a way that preserves civilian nuclear energy capabilities. Due to the dual-use nature of civilian nuclear energy facilities, those that are not currently under IAEA safeguards in NWS will likely need to be placed under safeguards to assure all Parties that those facilities are not being used for nuclear weapons production.

Control and Nonproliferation Verification, Presented at the Annual Meeting of the Institute of Nuclear Materials Management, 15-19 July 2012, Orlando, FL.

${ }^{114}$ Nuclear Threat Initiative (2012), Proposed Fissile Material (Cut-off) Treaty, www.nti.org/treaties-andregimes/proposed-fissile-material-cut-off-reaty/, accessed 12 November 2012. 


\subsubsection{Verification and Monitoring}

Verification measures for denuclearization treaties will cultivate additional confidence for nuclear disarmament treaties, providing assurance that states that are disarming limit their ability to re-build nuclear capabilities.

As technologies that can be used for verification measures expand, the legal framework will have to be considered for how to incorporate information from these technologies. This will include things like social media or societal verification, or engagement with disarmament watch groups.

\section{Multilateral Verification}

As is the case with future disarmament agreements, future denuclearization agreements will likely incorporate multilateral processes for verification or confidence building measures.

\section{Managed Access}

The non-governmental research organization Verification Research, Training, and Information Centre (VERTIC) has championed "managed access" as a verification mechanism for nuclear disarmament, in which inspectors gain access to highly sensitive facilities such as nuclear warhead disassembly sites. ${ }^{115}$ However, managed access could also be employed in future denuclearization treaties. Some measures for access to previously sensitive sites are already inplace under the current legal framework of the PPRA (1997), but could be increased under future regimes to include more access, to more types of facilities.

\subsection{Conclusions}

There exists a strong legal framework for further reductions in nuclear arsenals, with evolving inspection, monitoring, and confidence building measures. Russia and the United States will be able to continue nuclear disarmament, and denuclearization, to get their nuclear weapons stockpile down to a manageable size - one that is less expensive to maintain, and more on-par with other countries' nuclear arsenals. However, reducing numbers to very low levels will require a new level of international engagement and legal norms that are yet to be seen. Verification regimes would have to be more highly intrusive than ever before.

Denuclearization can likely be achieved to some extent, but the dual-use nature of nuclear energy technologies will mean that, unless we completely eliminate nuclear energy technologies, we won't get there. But, the submission of all civilian facilities to IAEA safeguards, with transparency and cooperation, could build confidence in the absence of militarization of the nuclear fuel cycle.

Kissinger and Scowcroft say that deep reductions alone might not be good for international security. They say that "strategic stability is not inherent with low numbers of nuclear weapons; indeed, excessively low numbers could lead to a situation in which surprise attacks are

115 VERTIC (2009), Verifiable Multilateral Nuclear Disarmament, Fact Sheet 9, April 2009. 
conceivable" ${ }^{116}$ In addition, they argue that nuclear reductions must consider how it will affect those countries under the American nuclear umbrella. States will have to work slowly over time to work up to broader regime. The future of nuclear disarmament and denuclearization will require a stable international security situation, and strong champions in all involved parties, whether that is NWS alone or also NNWS.

A future nuclear disarmament and denuclearization regime will rely on what Trevor Findlay calls a "learning by doing" process to increase "transparency and confidence building over many years". ${ }^{117}$ He points out that we learn not only from nuclear disarmament treaties like the INF, START I, and New START, but also from the NPT, the Biological and Toxin Weapons Convention (1972), and Chemical Weapons Convention (1992) in terms of inspections, verification, and compliance. Action will need to be taken to ensure that nuclear disarmament and denuclearization do not cause additional instability, such as in countries under a US nuclear security umbrella. Disarmament and denuclearization will have to be pursued in tandem, so that nuclear weapons that have been dismantled or destroyed are not readily replaced.

\footnotetext{
${ }^{116}$ Kissinger, H. and B. Scowcroft (2012), "Nuclear Weapons Reduction Must be Part of Strategic Analysis." Washington Post, 23 April 2012.

${ }^{117}$ Findlay, Trevor (2003), "Verification of a nuclear weapon-free world." Vertic Brief 1, May 2003.
} 